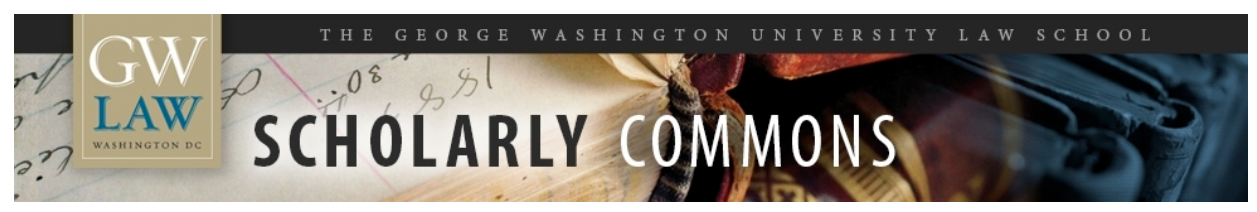

\title{
Deferred Prosecutions and Corporate Governance: An Integrated Approach to Investigation and Reform
}

Lawrence A. Cunningham

George Washington University Law School, lacunningham@law.gwu.edu

Follow this and additional works at: https://scholarship.law.gwu.edu/faculty_publications

Part of the Law Commons

\section{Recommended Citation}

Lawrence A. Cunningham, "Deferred Prosecutions and Corporate Governance: An Integrated Approach to Investigation and Reform" 65 FLA. L. REV. (forthcoming 2013).

This Article is brought to you for free and open access by the Faculty Scholarship at Scholarly Commons. It has been accepted for inclusion in GW Law Faculty Publications \& Other Works by an authorized administrator of Scholarly Commons. For more information, please contact spagel@law.gwu.edu. 


\title{
Deferred Prose cutions and Corporate Governance: AN INTEGRATED APPROACH TO INVESTIGATION AND REFORM
}

\author{
Lawrence A. Cunningham *
}

\begin{abstract}
$\underline{\text { Abstract }}$
When evaluating how to proceed against a corporate investigative target, law enforcement authorities often ignore the target's governance arrangements, while subsequently negotiating or imposing governance requirements, especially in deferred prosecution agreements. Ignoring governance structures and processes amid investigation can be hazardous and implementing improvised reforms afterwards may have severe unintended consequencesparticularly when prescribing standardized governance devices. Drawing, in part, on new lessons from three prominent cases-Arthur Andersen, AIG and Bristol-Myers Squibb-this Article criticizes prevailing discord and urges prosecutors to contemplate corporate governance at the outset and to articulate rationales for prescribed changes. Integrating the role of corporate governance into prosecutions would promote public confidence in prosecutorial decisions to broker firm-specific governance reforms currently lacking and increase their effectiveness. The Article, therefore, contributes a novel perspective on the controversial practice: though substantial commentary urges prosecutors to avoid intruding into corporate governance, this Article explains the importance of prosecutors investing in it.
\end{abstract}

\footnotetext{
* c 2013. Henry St. George Tucker III Research Professor of Law, The George W ashington University Law School. For hel pful comments, thanks to M iriam Baer, Stephanie Cuba, Lisa Fairfax, Roger Fairfax, B randon Garrett, Peter Henning, Renee Jones, Thomas M organ, M ichael Perino, Paul Radvany, A dam Spilka and William Wang. For the opportunity to present drafts of this Article as a work-in-progress, thanks to participants in workshops at B enjamin $\mathrm{N}$. Cardozo School of Law, Fordham University School of Law, New Y ork Law School and St. John's University School of Law.
} 


\section{$\underline{\text { Table of Contents }}$}

INTRODUCTION

I. Corporate Governance and Arthur Andersen

A. Definition and Variability 5

B. Movement and Power Shifts $\quad 7$

C. Compliance and the Rise of DPAs 11

D. Andersen's Seminal Lesson $\quad 15$

II. A IG, OVERSIGHT AND INATTENTION 18

A. AIG's Governance Profile $\quad 19$

B. Ex Ante M iscalculation 22

C. Ex P ost Standardization 25

III. An INTEgRATEd A PPROACH 29

A. Conceptualization: Contract, Regulation, Discretion 29

B. Comparative Benefits of the Integrated Approach 35

C. Costs and Other Potential Objections 41

IV. SpeCific Term S And BRISTOL-M yers SQUibB

A. Officers and Directors $\quad 45$

B. Charitable Giving 47

C. Monitors and Consultants 49

D. Shareholders and Disclosure $\quad 50$

$\begin{array}{ll}\text { CONCLUSION } & 51\end{array}$

APPENDICES

A. B ristol-M yers Squibb D PA 53

B. Prosecutors' Articulations on
Bristol-M yers Squibb DPA 


\section{INTRODUCTION}

"Prosecutors in the boardroom" is a slogan reflecting an unintended early $21^{\text {st }}$ century overlap of corporate governance and corporate criminal liability. ${ }^{1}$ Although exaggerated, the phrase reflects how prosecutors increasingly demand corporate governance reforms when settling criminal cases using deferred prosecution agreements (DPAs). ${ }^{2}$ W hile a growing body of scholarship seeks to put governance beyond the purview of prosecutors, ousting prosecutors from the boardroom, ${ }^{3}$ this Article explains why prosecutors should consider governance carefully in determining how to proceed ex ante and articulate rationales for governance changes in DPA s ex post.

Prosecutorial failure to consider governance ex ante can have adverse consequences, including activating governance mechanisms not designed to the purpose and imposing on corporate actors to hastily adopt changes that they would ordinarily evaluate and debate dispassionately. ${ }^{4}$ Subsequent prosecutorial prescriptions of governance changes are rarely the product of articulated rationales and can seem like ad hoc ransoms or trophies created on the fly by prosecutors seeking to claim victory. Irreconcilable criticisms result, with many observers saying that DPAs are coerced extractions of overzealous prosecutors while others say they are mere whitew ash that let corporate crooks off the hook. ${ }^{5}$

Prosecutors should publicly articulate the rationales for the governance changes they propose ex post and that articulation should be based on their assessment of the target's governance profile ex ante. Creating such an ex ante profile would involve modest incremental costs while improving the quality of prosecutorial decisions on how to proceed with a casesuch as whether to seek an indictment, what charges to bring, or whether to settle, and on what terms. Subsequent articulation of rationales would add substantial systemic benefits by increasing rationality, building credibility, deflecting criticism and creating a catalogue of knowledge useful in future prosecutions, regulation and governance design. This Article thus parts with critics of prosecutors in the boardroom by explaining the value of prosecutorial investment in corporate governance.

Part I of this A rticle first defines the concept of corporate governance- with notes on the governance of other business forms- and then highlights the most important developments of the corporate governance movement of the past two generations, distinguishing those features from compliance. While critics allow room for prosecutors to consider compliance in the

\footnotetext{
${ }^{1}$ It also inspired a book title. Prosecutors in the B oArdroom: Using Crim inal LaW to Regulate Corporate CONDUCT (A nthony Barkow \& Rachel Barkow eds., 2011).

${ }^{2}$ See Brandon L. Garrett, Structural Reform Prosecution, 93 VA. L. ReV. 853 (2007); Leonard Orland, The Transformation of Corporate Criminal Law, 1 BROOKLYN J. CORP. FIN. \& COM. L. 45 (2006).

3 E.g., Jennifer Arlen, Removing Prosecutors from the Boardroom: Deterring Crime Without Prosecutor Interference in Corporate Governance (2011), in PROSECUTORS IN THE BOARDROOM, supra note 1; see also M iriam Hechler B aer, Choosing Punishment, 92 B.U. L. REV. 578 (2012) (exploring reasons why ex post prosecution rather than ex ante regulation may occur and suggesting that the effects may leave society worse off).

${ }^{4}$ See Harry First, Branch Office of the Prosecutor: The New Role of the Corporation in Business Crime Prosecutions, 89 N.C. L. Rev. 23, 32-58 (2010); see also Samuel W. Buell, Criminal Procedure Within the Firm, 59 STAN. L. REV. 1613 (2007).

${ }^{5}$ Compare Richard A. Epstein, Op-Ed., The Deferred Prosecution Racket, W ALL ST. J. (N ov. 28, 2006) with Ralph Nader \& Robert Weissman, Letter to Alberto Gonzales (J une 5, 2006), available at http://www.multinationalmonitor.org/editorsblog/?p=30 (July 6, 2006, 15:34 EST) (discussing DPA with Boeing). The truth, undoubtedly, is somewhere in between.
} 
exercise of their discretion, this preliminary discussion stresses the importance of addressing governance, not merely compliance. The well-known story of the 2002 prosecution of the venerable accounting firm of Arthur Andersen is invoked to illustrate the underappreciated importance of governance. Many take the lesson of A ndersen's destruction by indictment to warn against indicting large business organizations. Part I, in contrast, draws the seminal lesson of Andersen: the prudence of prosecutorial consideration of governance when deciding how to proceed against a business.

Part II presents an original account of a more obscure but richer story: the 2005 prosecutorial probe into AIG. This explains how AIG's culpability at the center of the financial crisis of late 2008 was propelled by prosecutorial failure to evaluate its corporate governance realities in 2005. A nalysis reveals concern that prosecutors fail to appreciate how formal uniformity in corporate governance regulation masks considerable substantive variation and how this failure can be costly.

Part III turns conceptual and analytical to explore the relationship between prosecutors and corporate governance, particularly the proper scope of DPAs. One approach, implicitly reflected in the status quo, conceives of DPA $s$ as pure contract whose terms are limited only by standard contract doctrine; a mirror-image conception, critical of current practice, conceives of DPAs as pure regulation, which limits the range of proper terms to those targeting compliance, prohibiting broader aspects of corporate governance. A third conception, the most apt, recognizes DPA s as products of prosecutorial discretion, subject to prosecutorial restraint. In this view, DPAs warrant an integrated approach covering a wide range of terms, including governance terms, subject to prudential restrictions: prosecutors should only proffer such terms when they have assembled a formal governance profile of a target ex ante and publicly explain the rationale for such terms when announcing DPA s ex post. B enefits and costs are hypothesized and assessed, lending support to the integrated approach. ${ }^{6}$

Part IV returns to concrete ground to offer a series of examples of governance terms found in DPA s and credible rationales that prosecutors might have articulated. Examples include terms from the DPA in the case of Bristol-M yers Squibb, which drew sharp criticism, but prosecutors subsequently published a detailed explanation, ${ }^{7}$ illustrating the articulated rationale this Article prescribes. A ppendices excerpt governance terms of the B ristol-M yers Squibb DPA and related prosecutorial explanations, not so much to assert their optimality or ideality, but to suggest the feasibility of fulfilling this Article's prescriptions at reasonably low cost with valuable payoffs.

This Article concludes that the Department of Justice should lead by updating its guidelines for federal prosecutions of corporate targets to reflect the integrated approach and other prosecutors follow the lead. The DOJ has been reluctant to publish guidance on the subject of corporate governance reforms in DPA s. ${ }^{8}$ But this Article urges steps that should be more

\footnotetext{
${ }^{6}$ Costs are discussed infra text accompanying notes 218-221.

${ }^{7}$ Christopher J. Christie \& Robert M. Hanna, A Push D own the Road of Good Corporate Citizenship: The Deferred Prosecution Agreement Between the U.S. Attorney for the District of New J ersey and Bristol-M yers Squibb C $0 ., 43$ AM. CRIM. L. REV. 1043 (2006).

${ }^{8}$ Compare W ritten Testimony of B randon L. Garrett, U.S. House of Representatives, Committee on the J udiciary, Subcommittee on Commercial and Administrative Law, Deferred Prosecution: Should Corporate Settlement Agreements Be Without Guidelines? (M arch 11, 2008) (calling for DOJ to adopt clearer rules or guidance on corporate governance aspects of DPAs) with DOJ Letter to House Subcommittee (2008) (stating that "performance measures" in DPAs may be examined over time).
} 
congenial. The first is to add corporate governance as a factor to the existing list of factors prosecutors are told to consider when evaluating how to proceed with a case. ${ }^{9}$ The other, only slightly lengthier, would direct prosecutors to relate proffered governance reforms to that consideration in public articulations of their reasoning.

Looking at the same group of about 300 DPAs now in existence, those who seek to oust prosecutors from the boardroom see frequent and extensive incursions into corporate governance that must be repelled while those who perceive excessive leniency are eager for greater prosecutorial inroads into governance. Under the integrated approach, the exact DPA population or density of governance terms becomes less important than whether there is investigation ahead of time and an articulated rationale afterwards.

\section{Corporate Governance and Arthur Andersen}

Prosecutors must appreciate both the variety of corporate governance, and the varying governance regimes across different forms of business organization, when deciding how to proceed in a criminal case against a business and when settling. ${ }^{10}$ Instead, they talk in sweeping vague terms about rehabilitation of corporate cultures-for example, from a "culture of corruption or criminality" to a "culture of compliance." ${ }^{11}$ This Part defines corporate governance; highlights the achievements and shortcomings of the corporate governance movement of the past two generations; and distinguishes governance from compliance. It concludes by drawing a new lesson from an old story: the 2002 federal indictment of A rthur A ndersen does not necessarily stand for the idea that prosecutors should refrain from indicting large businesses because doing so presents adverse collateral consequences for innocent parties. ${ }^{12}$ Rather, the seminal lesson is that prosecutors made the mistake of failing to assess or understand Arthur Andersen and its governance; had they been more careful, they would not have indicted the firm.

\section{A. Definition and Variability}

Corporate governance is a capacious notion applicable to any business organization, encompassing business purpose and the mechanisms within a firm to achieve it. Purposes vary across companies and any given one may have multiple purposes. A common purpose in the United States for publicly-traded companies is to maximize stock price and for all companies to maximize net profits available for distribution to owners. Some companies, such as Ben \& Jerry's Ice Cream, adopt policies more geared to promoting social objectives, while others, such

\footnotetext{
${ }^{9}$ See infra notes $68 \& 264$ and accompanying text.

${ }^{10}$ The popular press portrayed prosecutors as anemic in failing to charge individuals or firms with crimes arising out of the financial crisis of 2008. E.g., Editorial, No Crime, No Punishment, N.Y. TIM ES (A ug. 26, 2012). Prosecutors explained that abstinence was not for lack of power but for lack of evidence, with both the DOJ and the SEC noting that they had conducted in-depth an unhindered investigation into numerous firms, including Goldman Sachs.

${ }^{11}$ See Peter J. Henning, Corporate Criminal Liability and the Potential for Rehabilitation, 46 AM. CRIM. L. Rev. 1417 (2009); Brandon L. Garrett, TOO Big to JaIl: How Prosecutors Take on Corporations ch. 3 (forthcoming 2013) (draft manuscript on file with author and cited with permission); U.S. A ttorney, District of N ew Jersey, Press Release, W right M edical (October 5, 2012) (boasting of inducing target to "implement a compliant corporate culture").

12 See infra text accompanying notes 72-89.
} 
as J ohnson \& J ohnson, state corporate purpose as advancing the interests of a list of stakeholders in given orders, such as customers, employees, communities and shareholders. ${ }^{13}$ Greater variation appears among non-U.S. companies. ${ }^{14}$

Organizational arrangements bearing on the pursuit of business purpose address the board of directors, officers, employees and owners. ${ }^{15}$ Terms concern board size and procedures and director selection and identity; officer functions and reporting protocols and leadership attitudes and philosophies; and employee training and organizational policies and procedures. Features include shareholder demographics, such as the degree of ownership by institutional investors and individual investors; and the firm's directors, officers and employees. They also include the characteristics of any controlling shareholder and whether a firm is publicly-traded.

Further delineation of an overall governance profile reaches matters of employee compensation and morale as well as internal controls, including compliance with law. A corporation's regulatory environment can be important too, especially for firms in highlyregulated industries where criminal prosecution-or even indictment-can expose firms to debarment from government contracts or licenses. Within this framework, governance may encompass how professional advisors such as auditors and lawyers are recruited, supervised and paid. A mong a potpourri of other attributes of governance are such topics as charitable giving, political speech and CEO succession. Finally, the subjects of financial reporting and disclosure are also critical aspects of corporate governance for publicly-traded companies.

Corporate governance therefore includes a wide variety of features. They may be products of norms, practices, history, culture, contract, bylaw, charter, regulation or statute. Some features are definite, observable and changeable by law or bargain, such as the type and number of directors and how employees are trained and paid. Others are more fluid, intangible and persistent, such as a tone at the top, employee culture and shareholder apathy or activism. Given such variety within companies, corporate governance changes have vastly different effects on each company.

A Ithough corporate governance literally denominates governance of the corporate form of business organization, the concepts and issues apply to other forms of business organization as well-including partnerships, limited liability companies and others. Ownership and control and related governance attributes in those forms vary further. For example, partnerships tend to involve a greater degree of participation in management among the partners and partner capital investments consist of skills and reputation as well as money.

Understanding what makes a given business organization tick requires a rudimentary grasp of such governance attributes, including an appreciation that what works for one enterprise may or may not work for another. A s important, developments in the broader field of business law in recent generations have emanated from the corporate form, especially those associated with the corporate governance movement.

\footnotetext{
${ }^{13}$ See Lewis D. Solomon, On the F rontier of Capitalism: Implementation of H umanomics by M odern Publicly Held Corporations: A Critical Assessment, 50 W ASH. \& LEE L. ReV. 1625 (1993).

${ }^{14}$ See Lawrence A. Cunningham, Commonalities and Prescriptions in the Vertical Dimension of Global Corporate Governance, 84 CORNELL L. REV. 1133 (1999).

${ }^{15}$ See A merican La W Institute, Principles of Corporate GovernanCe (1994).
} 


\section{B. Movement and Power Shifts}

Beginning in the 1970s, a corporate governance movement emerged to contend that corporations should maximize shareholder value. Proponents advocated devices adapted to that end focused on the role of officers, directors and shareholders. Until then, during most of the $20^{\text {th }}$ century in A merica, boards of directors tended to be characterized as a collegial body operating in an atmosphere of trust and informality. ${ }^{16}$ Largely for reasons of historical and political accident, managers were strong, directors supportive and shareholders, especially in publiclytraded firms, weak. ${ }^{17}$ This structure was famously described in the 1930 s by Berle and M eans as resulting in the separation of corporate ownership from corporate control. ${ }^{18}$

The corporate governance movement, along with a burgeoning scholarly literature, forged change in the traditional model in the 1970s. Demand for change rose due to a combination of social, business and legal factors, including corporate scandals that alienated shareholders, and judicial and regulatory reformers eager for change. ${ }^{19}$ For shareholder advocates, the original goal of this movement was to focus corporations on the purpose of maximizing shareholder value; in the legal literature, the objective was expressed in terms of reducing agency costs associated with the separation of ownership from control in publiclytraded corporations. ${ }^{20}$ Other proponents stressed broader concerns about civic responsibility. ${ }^{21}$

Institutional Investors. The most significant development in the modern history of corporate governance has been the rise in institutional ownership of corporate stock. ${ }^{22}$ Since the 1970s, with increasing ownership through today, a steadily growing percentage of the equity of large U.S. corporations has come to be owned not by individuals, as historically occurred, but by institutional investors, such as pension plans, private foundations and mutual funds. ${ }^{23}$ These institutional investors drove the corporate governance movement.

With vast pools of capital, along with associated votes in corporate director elections, concentrated in fewer hands, shareholders gained greater influence in corporate boardrooms. In particular, institutional shareholders held out the promise of overcoming the costs of collective action and the problem of rational apathy that plagued individual shareholders and limited their power. ${ }^{24}$

Active shareholders- such as the California Public Employees Retirement System or CalPers-succeeded in transforming many aspects of corporate governance. Watershed accomplishments include the landmark amendments to the federal proxy rules in 1993 that

\footnotetext{
${ }^{16}$ See M YLES M ACE, DIRECTORS: M Y TH AND REALITY (1971).

17 See Mark J. Roe, Strong Managers, Weak Owners: The Political Roots of american Corporate FINANCE (1996).

${ }^{18}$ Adolph A. Berle \& Gardiner Means, The M odern Corporation and Private Property (1932).

${ }^{19}$ See Melvin Eisenberg, The Structure of the Corporation: A Legal Analysis (1976).

${ }^{20}$ See Frank H. Easterbrook \& Daniel R. Fischel, The Economic Structure of Corporate law (1996).

${ }^{21}$ E.g., ROBERT A.G. M ONKS \& NELL M IN OW, POWER ANd A CCOUNTABILITY (1991).

${ }^{22}$ See M arcel Kahan \& Edward B. Rock, The E mbattled CE 0, 88 TEXAS L. REV. 987 (2011).

${ }^{23}$ See Gary J. Previts, A Pie Chart View of US Publicly Traded Corporate Equity Distribution: 1950-2011 (slide show presentation on file with the author); see also M artin Gelter, The Pension System and the Rise of Shareholder Primacy (draft manuscript 2012, available at www.ssrn.com/abstract=2079607).

${ }^{24}$ Directors began to pay more attention to shareholder "voice," offering shareholders an alternative to the only traditional way to object to disappointed expectations, which was to "exit," meaning to sell the stock (once called the Wall Street rule). Cf. A Lbert O. HIRSCHMAN, EXIT, V OICE AND LOYALTY: RESPONSES TO DECLINES IN FIRMS, ORGANIZATIONS, AND STATES (1970).
} 
improved the ability of such investors to communicate with one another and plan coordinated campaigns to advance their corporate governance agendas. ${ }^{25}$ Further manifestations include increased frequency and adoption of shareholder proposals addressed to governance rather than social issues and expanding shareholder access to the corporation's own proxy statement for the election of directors (so-called "proxy access"). ${ }^{26}$ Such shareholders also campaigned for specific corporate governance devices, such as prohibiting the same person from serving as both board chairman and CEO, holding executive sessions of the board attended solely by outsiders and imposing age limits for directors.

Outside Directors. But the single greatest consequence of the rise of institutional shareholders-and the other most significant achievement of the corporate governance movement- has been the consequent rise in the number and power of outside directors- those not otherwise employed by or associated with the corporation. ${ }^{27}$ Outside directors were seen as a mechanism for monitoring management and therefore reducing agency costs. ${ }^{28}$ They promised a unique ability to render independent judgments and promote shareholder value. ${ }^{29}$

Reinforcing the institutional investor appetite for outside directors, laws and regulations also increased their number and power. State corporation law in the 1980s encouraged boards to have outside directors, especially for tasks such as evaluating takeovers and other transactions posing conflicts of interest. ${ }^{30}$ In federal securities law, the Sarbanes-Oxley A ct of 2002 expanded the power of outside directors, concerning the auditing function, including giving outside directors plenary power over the company's auditor. ${ }^{31}$ The Dodd-Frank Act of 2010 created similar requirements concerning compensation committees. ${ }^{32}$ As a result of institutional shareholder preferences for outside directors and regulatory enthusiasm, today's boards of the largest publicly-traded corporations often have no more than one or two inside (management) directors. ${ }^{33}$

${ }^{25}$ See Jill A. Hornstein, Proxy Solicitation Redefined: The SEC Takes an Incremental Step Toward Effective Corporate Governance, 71 W ASH. U. L. Q. 1129 (1993).

${ }^{26}$ See K ahan \& Rock, E mbattled CEO, supra note 22; Jill E. Fisch, The Destructive Ambiguity of Federal Proxy Access, 61 Emory L. J. 435 (2012); Lisa M. Fairfax, The Future of Shareholder Democracy, 84 IND. L.J. 1259 (2009).

${ }^{27}$ See Ronald J. Gilson, Reinventing the Outside Director: An Agenda for Institutional Investors, 43 STAN. L. ReV. 863 (1991). The concepts of outside and inside directors are vernacular terms whose precise definitions vary with context but the distinction generally is between directors who are employees of a company (inside) and those who are not (outside). M ore particular distinctions attempt to define a notion of "independent" to denominate directors whose lack of employee or other corporate status enable them to exercise judgments free of conflict of interest. Specific and varying definitions of director independence appear in such authorities as the federal securities laws, state corporation laws, stock exchange rules, corporate and board committee charters, corporate contracts and various law reform documents. See Donald C. Clarke, Three Concepts of the O utside Director, 32 DEL. J. CORP. L. 73 (2007).

${ }^{28}$ See John C. Coffee, J r., Liquidity versus Control: Institutional Investors as M onitors, 91 CoLUM. L. REV. 1191 (1991).

${ }^{29}$ See J effrey N. Gordon, The Rise of Independent Directors in the U nited States, 1950-2005: Of Shareholder Value and Stock Market Prices, 59 STAN. L. REV. 1465 (2007).

${ }^{30}$ E.g., Weinberger v. U OP, Inc. 457 A.2d 701 (Del. 1983); Paramount Communications, Inc. v. Time Inc., 571 A. 2d 1140 (Del. 1989); Paramount Communications Inc. v. QVC Network Inc., 637 A.2d 34 (Del. 1994); DEL. GEN. CORP. L. § 144; M ODEL BUS. CORP. ACT, § 8.61.

${ }^{31}$ Sarbanes-Oxley A ct of $2002, \S 301$.

32 Dodd-Frank Wall Street Reform and Consumer Protection Act (Pub. L. 111-203), § 952; see also S.E.C. Rue $10 \mathrm{C}-1(\mathrm{~b})(1))$ (implementing the statutory directives as required).

${ }^{33}$ See Lisa M. Fairfax, The Uneasy Case for the Inside Director, 96 IowA L. REV. 127 (2010). 
Gatekeepers. The third most significant development of the corporate governance movement concerned the role of professional advisors, called gatekeepers. These are participants in corporate process, traditionally auditors and lawyers, who stake their reputation when vouching for the validity or integrity of corporate decision-making. ${ }^{34}$ In financial reporting, for instance, auditors attest to the truth and fairness of accounting results, and in raising capital, lawyers conduct due diligence to assure the legality of the offering and veracity of the issuer's descriptions in accompanying offering documents. ${ }^{35}$ Though such professionals had been involved in these transactions throughout the prior century, the corporate governance movement amplified the importance of their role. ${ }^{36}$ In a recent trend, outside directors have retained their own lawyers to represent them. Historically, outside directors had not hired their own lawyers, but Sarbanes-0xley authorized audit committees to do so. $^{37} \mathrm{~A}$ specialty legal practice emerged: representing outside directors, especially advising on disagreements with chief executives. ${ }^{38}$

Shortcomings. There are several shortcomings in these corporate governance developments. First, it is not always clear that the rise of institutional investors or outside directors reduced agency costs as much as promised or that many of the other devices do so consistently. Institutional investors, after all, manage money for others, meaning they are agents as well for their investors, and those investors face the costs of having those agents manage their money. The rise in power of institutional investors may have reduced one set of agency costs while creating another set in its place. Debate contested the net effects. ${ }^{39}$ Further, institutional investors are not homogenous, but vary in such features as relative activism or passivity and goals, with most stressing shareholder value but many engaging in "socially responsible investing" that addresses varied objectives such as environmental protection or human rights. ${ }^{40}$

Concerning outside directors, empirical research never provided much evidence that their presence improves shareholder value or corporate performance. ${ }^{41}$ Some evidence suggests that

${ }^{34}$ Reiner H. Kraakman, Gatekeepers: The Anatomy of a Third-Party Enforcement Strategy, 2 J. L. EcoN. \& STRATEGY 53 (1986).

${ }_{35}$ See Lawrence A. Cunningham. Sharing Accounting's Burden: Business Lawyers in Enron's Dark Shadows, 57 BUS. LAW. 1421 (2002).

${ }^{36}$ See A braham J. Briloff, The Corporate Society: We are In Pari D elicto, 1 J. CoRP. L. 457 (1976); Lincoln Savings \& Loan Ass' $n$ v. Wall, 743 F. Supp. 901,920 (D.D.C. 1990) (Sporkin, J.) Evidence of the importance attached to the gatekeeping function is clear from the expanding list of professionals who can provide such a service, which today includes rating agencies, research analysts, D\&O insurers and investment banks. See CLAIRE A. HILL \& BRETT H. M CDONNELL, RESEARCH HANDBOOK ON THE ECONOMICS OF CORPORATE LAW (2012) (including pieces about such gatekeepers by Lawrence A. Cunningham, Jill E. Fisch, Tamar Frankel, Sean J. Griffith, Richard W. Painter and Frank Partnoy).

${ }^{37}$ Proposals to equip outside directors with power to retain independent advisors remained rare even after being ordained in 1994 by the A merican Law Institute. ALI, PRINCIPLES OF CORPORATE G OVERNANCE $§ 3.04$ (1994); see also James D. Cox, Managing and Monitoring Conflicts of Interest: Empowering the 0 utside Directors with Independent Counsel, 48 V ILLANOVA L. ReV. 1077 (2003) (making "modest" proposal that outside directors asked to approve interested transactions of other directors retain their own lawyer).

${ }^{38}$ A mong the earliest and most prominent examples of outside lawyers exerting power in the boardroom to oust a chief executive occurred when Ira Millstein, of Weil, Gotshal \& M anges, played that role in 1992's dismissal of General Motors CEO Robert Stempel. See John A. Byrne, The Guru of Good Governance, Bus. Wk. (A pril 28, 1997), p. 100; A lison Leigh Cowan, The High-Energy Board Room, N.Y. TIM ES (Oct. 28, 1992).

${ }^{39}$ See Bernard S. Black, Agents Watching Agents: The Promise of Institutional Investor Voice, 39 UCLA L. REV. 811 (1992).

${ }^{40}$ See Carolyn Kay Brancato, Institutional InVestors and Corporate GovernanCe 87 (1997).

41 E.g., Sanjai Bhagat \& Bernard Black, The Uncertain Relationship Between Board Composition and Firm Performance, 54 BuS. LAW. 921 (1999); Sanjai B hagat \& Bernard Black, The Non-Correlation Between Board 
what matters is not so much a board's independence as its active engagement. ${ }^{42}$ There is also evidence that certain kinds of outside directors improve the performance of certain functions, such as adherence to accounting requirements. ${ }^{43}$ But, clearly, there is a trade-off between the expertise commanded by inside (management) directors and the independence that outside directors offer. ${ }^{44}$

Debate continues over the exact value of gatekeepers and ways to improve their effectiveness. ${ }^{45} \mathrm{An}$ acute case concerns the new practice of outside directors retaining independent counsel to advise them, especially on disagreements with management. Some experts see this development as perilous, as it cleaves boards into factions, injects lawyers deeply into corporate deliberations and compromises the independence of directors when lawyers advise them of what is best for them personally rather than one is best for the corporation. ${ }^{46} \mathrm{H}$ owever, in some cases outside directors have assumed considerable power and authority in corporate boardrooms and have been exposed to personal liability - most notably in the cases of Enron and W orldCom. ${ }^{47}$

Studies and debate concerning corporate governance features correctly suggest that any given governance reform, from adding outside directors to having the audit committee supervise outside auditors, could have differing effects from company to company. ${ }^{48}$ Such differences expose a final weakness about the corporate governance movement: it often advanced reforms for adoption generally that overlooked variation among companies. ${ }^{49}$ That has been especially problematic concerning governance devices adopted in the aftermath of corporate scandal. ${ }^{50}$

Despite broad observable phenomena such as the rise of institutional investors or outside directors and changeable terms such as the staffing and duties of audit committees, there remains considerable variation in relevant corporate governance attributes at particular companies. Thus boards may be required-by law, stock exchange rule or shareholder mandate-to produce governance guidelines, committee charters or ethics codes, but the resulting products and effects

Independence and Long-Term Firm Performance, 27 J. CORP. L. 231 (2002); Benjamin E. Hermalin \& M ichael S. W eisbach, Boards of Directors as an Endogenously Determined Institution: A Survey of the Economic Literature, Federal Reserve Bank OF N.Y. ECon. Policy Rev. A pril 2003), at 7.

${ }^{42}$ See Ira Millstein \& Paul MacA voy, The Active Board of Directors and Improved Performance of the Large Publicly-Traded Corporation, Y ale School of M anagement W orking Paper N o. 49 (1997).

${ }^{43}$ See Lawrence A. Cunningham, Rediscovering Board Expertise: Legal Implications of the Empirical Literature, 77 CINCINNATI L. REV. 465 (2008).

${ }_{44}^{44}$ Id.; U sha Rodrigues, The F etishization of Independence, 33 J. CORP. L. 447 (2008).

${ }^{45}$ See J ohn C. Coffee, JR., Gatekeepers: Failure And Reform (2006).

${ }^{46}$ See, e.g., E. N orman V easey, Separate and Continuing Counsel for Independent Directors: An Idea Whose Time Has Not Come as a General Practice, 591413 (2004); see also Geoffrey C. Hazard, Jr. \& Edward B. Rock, A New Player in the Boardroom: The Emergence of the Independent Directors' Counsel, 59 BuS. LAW. 1389 (2004) (offering tepid acceptance of the concept).

${ }^{47}$ See infra text accompanying notes 66-70.

48 See Donald C. Langevoort, The Human Nature of Corporate Boards: Law, Norms and the Unintended Consequences of Independence and Accountability, 89 GEO. L.J. 797 (2001); Jill E. Fisch, Taking Boards Seriously, 19 CARDOZO L. REV. 265 (1997).

${ }^{49}$ See Larry E. Ribstein, The M andatory Nature of the ALI Code, 61 GEO. W ASH. L. REV. 984 (1993).

${ }^{50}$ See Roberta Romano, The Sarbanes-0 xley Act and the Making of Quack Corporate Governance, 114 Y ALE L.J . 1521 (2005); Larry Ribstein, Bubble Laws, 40 Houston L. ReV. 77 (2003); Stuart Banner, What Causes Securities Regulation? 300 Years of Evidence, 75 W ASH. U. L. Q. 849 (1997). This literature addresses generally-applicable laws and regulations adopted in response to financial crises, not the individualized setting of DPAs, which differs, as noted infra text accompanying notes 203-204. 
are unlikely to be identical at different firms. Indeed, some governance regulations explicitly recognize that one size does not fit all, as when certain devices are required only of large companies and waived for smaller ones. ${ }^{51}$

LLCS and LLPS. A final notable phenomenon in the development of business law in the past two generations has been the proliferation of alternative forms of business organization. The rise of the limited liability partnership and the limited liability company are the most prominent examples. These trace their origins to the limited partnership and the corporation, respectively, and are defined by the high degree to which investors in them may enjoy the benefits of limited liability along with other advantages. A t one time, entrepreneurs had to accept trade-offs among alternative forms of business organization, such as between the limited shareholder liability of the corporate form that was subject to two levels of taxation or the single taxation of the partnership that exposed partners to unlimited liability. The rise of these alternative forms has eliminated such trade-offs, thanks to statutory and contractual innovations that combine the appealing attributes of historical forms of business organization into modern hybrids. ${ }^{52}$ Governance features in these new forms of business organization are extensively tailored by contract and therefore even more variable than the traditional partnership and corporation.

\section{Compliance and the Rise of DPAs}

The subject of compliance is a narrow component of corporate governance with roots anchored not so much in the corporate governance movement but in the concurrent intensification of organizational criminal liability. Although corporate-level criminal liability was recognized in a famous 1909 case, ${ }^{53}$ throughout most of the $20^{\text {th }}$ century, organizational criminal liability remained relatively rare. During the 1970s, however, an eruption of corporate scandals inspired law enforcement authorities to strengthen its policing of corporate behavior. ${ }^{54}$ The Watergate-induced disclosures of corporate wrongdoing around the world by U.S. companies, such as the widespread bribery of foreign officials, prompted legislation cracking down on such practices. ${ }^{55}$ Congress strengthened criminal penalties under federal law across many fields, from antitrust to environmental to securities. Prosecutions ensued against corporations with household names, such as Drexel Burnham Lambert in finance and Exxon for the $V$ aldez oil spill. ${ }^{56}$

Compliance. The general approach held corporations vicariously liable for acts of their agents taken within the scope of employment. ${ }^{57}$ Policing corporate wrongdoing through criminal

\footnotetext{
${ }^{51}$ E.g., W all Street Reform and Consumer Protection A ct, Pub. L. No. 111-203, § 989G, 103 Stat. 440 (2009) (ddFrank A ct relieving internal control audit obligations for certain smaller public companies); J umpstart Our B usiness A ct ("JOBS A ct") of 2012, Pub. L. No. 112-106, §501, 126 Stat. 306, 325 (2012) (to be codified at 15 U.S.C. $781(g)(1)(A))$.

52 E.g., LARRY E. RibStein, The Rise of the UnCORPoration (2009).

${ }^{53} \mathrm{~N}$ ew York Central \& Hudson River R.R. v U nited States, 212 U.S. 481 (1909).

${ }^{54}$ John C. Coffee, Jr., "No Soul to Damn: No Body to Kick": An Unscandalized Inquiry into the Problem of Corporate Punishment, 79 M ICH. L. REV. 386 (1981).

${ }^{55}$ See W alter Perkel, The F oreign Corrupt Practices Act, 40 A M. CRIM L. Rev. 683 (2003).

${ }^{56}$ See Daniel R. Fischel, Payback: The Conspiracy to Destroy Michael Milken and his Financial REVOLUTION (1995).

${ }^{57}$ M ore sweeping variations were formulated as well. E.g., U nited States v. Bank of New England, 821 F.2d 844 (1 $1^{\text {st }}$ Cir. 1987) (collective knowledge standard: the sum total of employee knowledge across a corporation can be attributed to it).
} 
law assumed a more formal dimension with the formation of the U.S. Sentencing Commission in 1987 and the organizational sentencing guidelines it produced over the next few years. ${ }^{58}$ This codified an approach to deterring corporate crime through a calibrated sentencing format. It gave corporations credit in sentencing for having effective compliance programs in place as well as cooperating with lawmakers to conduct requisite investigations and assist in resulting prosecutions. This amounted to a slight shift from the traditional standard of vicarious liability to a modified duty-based approach to liability. ${ }^{59}$ That is, corporate exposure came to hinge on the relative effectiveness of a corporation's compliance program. ${ }^{60}$

The importance of effective compliance programs became more central to corporate life after 1996 when the Delaware Court of Chancery announced clear compliance duties of corporate directors. ${ }^{61}$ Drawing in part on the federal organizational sentencing guidelines, that opinion questioned the continuing soundness of a 1963 Delaware Supreme Court opinion that limited any such duties to cases where red flags would have stimulated a reasonable director's attention. ${ }^{62}$ The Chancery opinion said that corporate directors must take reasonable efforts to assure that the firm maintains effective compliance programs, a stance later validated by the Delaware Supreme Court. ${ }^{63}$

The holding was narrow and arose in the settlement of a derivative suit that required only assessing whether a settlement was fair. But it spawned extensive commentary and expanded work for consultants as companies scrutinized internal compliance programs. ${ }^{64}$ Scholars, meanwhile, questioned whether the preoccupation with compliance could produce cosmetic exercises in window dressing rather than substantive control over internal corporate agents. ${ }^{65}$ A fter all, compliance systems - or governance structures - are rarely effective unless both senior management and individuals responsible for maintaining them believe in and endorse them. Employees and other constituents pick up on signals about whether management holds such commitments or is merely going through the motions.

Enforcement Intensity and Andersen. The era of Enron and Sarbanes-Oxley brought renewed intensity to corporate criminal law, just as it did to corporate governance. ${ }^{66}$ SarbanesOxley, enacted in 2002, defined new crimes for wrongful financial statement certification, enhanced penalties for other business crimes and directed the Sentencing Commission to assure optimal approaches to corporate criminal liability. President George W. Bush formed the

\footnotetext{
${ }^{58}$ See llene M. Nagel \& Winthrop M. Swenson, The Federal Sentencing Guidelines for Corporations: Their Development, Underpinnings and Some Thoughts About Their F uture, 71 W ASH. U. L.Q 205 (1993).

${ }^{59}$ See J ennifer A rlen \& Reinier K raakman, Controlling Corporate Misconduct: An Analysis of Corporate Liability Regimes, 72 N.Y.U. L. REV. 687 (1997).

60 See Jennifer Arlen, The Potentially Perverse Effects of Corporate Criminal Liability, 23 J. LegAL STUD. 833 (1994).

${ }^{61}$ In re Caremark Int'I, 698 A.2d 959 (Del. Ch. 1996).

${ }^{62}$ Graham v. Allis-Chalmers, 188 A.2d 125 (Del 1963).

${ }^{63}$ Stone v. Ritter, 911 A .2d 362 (Del. 2006).

${ }^{64}$ See H. Lowell Brown, The Corporate Director's Compliance Responsibility in the Post Caremark Era, 26 DEL. J. CORP. L. 1 (2001); Charles M. Elson \& Christopher J. Gyves, In re Caremark: Good Intentions, Unintended Consequences, 39 W AKE FOREST L. REV. 691 (2004).

${ }^{65}$ E.g. K imberly D. Krawiec, Cosmetic Compliance and the Failure of Negotiated Governance, 81 W ASH. U. L. Q. 487 (2003); Lawrence A. Cunningham, The Appeal and Limits of Internal Controls to Fight Fraud, Terrorism, 0 ther IIIS, 29 J. CORP. L. 267 (2004).

${ }^{66}$ See Lawrence A. Cunningham, The Sarbanes-0xley Yawn: Heavy Rhetoric, Light Reform (And It Might J ust Work), 35 CONN. L. REv. 915 (2003).
} 
President's Corporate Fraud Task Force within the Department of J ustice to fortify this area of law enforcement. ${ }^{67}$ The government's rationale was outlined in a series of J ustice Department memos "getting tough" on corporate malfeasance, a 2003 version of which stressed "vigorous enforcement" of law against "corporate wrongdoers." 68 The focus remained on corporate compliance programs as the key to optimal deterrence, with a new emphasis on mandatory cooperation that intensified the internal policing of corporate employees. ${ }^{69}$

In response, prosecutors escalated high-profile suits against esteemed corporate directors and prominent auditing firms. A symbol of the seismic shift in enforcement occurred when 20 directors of Enron and WorldCom paid $\$ 31$ million out of their pockets, unreimbursed by insurance or indemnification, to settle suits against them. ${ }^{70} \mathrm{~W}$ hether desirable or not, directors across corporate A merica began to fear for their personal liability.

A stunning result of the Enron-era enforcement intensification occurred in 2002 when the DOJ filed criminal charges for obstruction of justice against the venerable independent accounting firm of Arthur A ndersen, whose Houston office had signed off on Enron's books. During the government's investigation, two senior Andersen employees destroyed drafts of documents relating to the work. For that, the government indicted the entire firm, then employing 85,000 and earning billions annually, and won a fine of $\$ 500,000$. Negotiations between prosecutors and the firm to avoid that result, by a contractual settlement, failed when the two could not agree on the firm's admission of wrongdoing. ${ }^{71}$ Though a unanimous U.S. Supreme Court eventually overturned the firm's later conviction, by then the prosecutorial enthusiasm had destroyed the firm. ${ }^{72}$

Proliferation of DPAs and Controversy. After Andersen, prosecutors often became reluctant to indict entire firms that employed large numbers of innocent people, though they continued to hold that threat over the heads of top corporate officials. ${ }^{73}$ Such reluctance led to

\footnotetext{
${ }^{67}$ See http://www.justice.gov/archive/dag/cftf/. President B arack Obama expanded the program under a new name, the Interagency Financial Fraud Task Force. See http://www.sec.gov/news/press/2009/2009-249.htm.

${ }^{68}$ The memos were signed by successive Deputy Attorneys General of the U.S., the first of which issued in 1999. See Memorandum from Eric Holder, Deputy Attorney General, U.S. Dept. of J ustice, to Heads of Department Components and United States Attorneys, Bringing Criminal Charges Against Corporations (J une 16, 1999); M emorandum from Larry D. Thompson, Deputy Attorney General, U.S. Dept. of J ustice, to Heads of Department Components and U nited States A ttorneys, Principles of $\mathrm{F}$ ederal Prosecution of Business Organizations (J anuary 20, 2003); Memorandum from Paul J. McNulty, Deputy A ttorney General, U.S. Dept. of Justice, to Heads of Department Components and U nited States A ttorneys, Principles of F ederal Prosecution of Business Organizations (December 12, 2006), www.usddoj.gov.dag/speeches/2--6/mcnulty memo.pdf; M emorandum from M ark Filip, Deputy A ttorney General, U.S. Dept. of Justice, to Heads of Department Components and U nited States A ttorneys Principles of Federal Prosecution of Business Organizations (Aug. 28, 2008), www.usdog.gov.dag/readingroom/dag/dag-memo-08282008.pdf.

${ }^{69}$ See M iriam Hechler Baer, Governing Corporate Compliance, 50 B .C. L. Rev. 949 (2009).

${ }^{70}$ See Bernard Black, Brian R. Chefffins \& M ichael Klausner, O utside Director Liability, 58 STAN. L. Rev. 1055 (2006).

${ }^{71}$ The sticking point was important because the exact admission would influence the Securities and Exchange Commission's decision about debarring the firm from auditing public companies-its bread and butter-a concern over civil consequences of the criminal procedure. See Kathleen F. B rickey, Andersen's F all from G race, 81 W ASH. U.L.Q. 917 (2003).

${ }^{72}$ Arthur Andersen LLP v. U nited States, 544 U.S. 696 (2005).

${ }^{73}$ See Elizabeth K. A inslie, Indicting Corporations Revisited: Lessons from the Arthur Andersen Prosecution, 43 A M. CRIM . L. Rev. 107 (2006); A ndrew Weissman \& David Newman, Rethinking Corporate Criminal Liability, 82 IND. L. J 411 (2007); J ames K elly, The Power of an Indictment and the Demise of Arthur Andersen, 47 S. TEXAS L. REV. 509 (2006).
} 
the proliferation of deferred prosecution agreements (DPAs), in which firms opt for cooperative settlement, avoiding the feared fate of doom. In DPA s, prosecutors agree with target corporations (and other organizations or even individuals) to defer or refrain from prosecution in exchange for the target admitting allegations, paying fines and committing to various undertakings. ${ }^{74}$ Corporate undertakings include reforms such as detailed public disclosure of the matter, enhanced internal compliance programs and top-level governance changes. Terms provide that prosecution is deferred. However, if the government determines that the target breached, it can prosecute. A t such a time, given the admissions, conviction is potentially certain. ${ }^{75}$

DPA s are age-old devices, but have become popular in the U.S. only in the past decade: barely a couple dozen were ever used before 2003, but nearly 300 have been signed since. ${ }^{76}$ During the summer of 2012 al one, federal prosecutors around the country entered into a dozen of them with various corporate targets. ${ }^{77}$ In late 2012, the United Kingdom opted to follow this A merican development. ${ }^{78}$ Other countries are doing so as well. ${ }^{79}$ Nevertheless, while DPAs may be both popular among prosecutors and some corporations, they are controversial among scholars and policymakers, provoking negative commentary. ${ }^{80}$

\footnotetext{
${ }^{74}$ Technically, prosecutors distinguish between deferred prosecution agreements (DPAs) and non-prosecution agreements (NPAs) but the distinction is immaterial to the questions addressed here concerning the legitimacy of including corporate governance terms in any such agreements. NPA s are typically used in cases where no criminal charges are filed while DPAs are reached to settle filed charges. Court approval is involved in the latter but not the former case, though little or no judicial second-guessing occurs. See infra text accompanying notes 168-176.

${ }^{75}$ DPAs cam resemble structural reform litigation developed through consent decrees in the civil rights area and resemble contemporary regulatory agency settlements. See Garrett, supra note 2, at 869-874 (noting parallels to and differences from structural reform litigation evaluated in the landmark work, A bram Chayes, The Role of the J udge in Public Law Litigation, 89 HARV. L. REV. 1281 (1976)). DPAs invert the consent decree model, however, as they target private rather than pubic actors and enforce criminal law not civil rights. As for administrative settlements, apart from the civil/criminal distinction- and related risks of collateral consequences- they more often than DPAs do not require admissions of facts or guilt and do not routinely entail commitments to reform compliance and governance. Agencies also bring the expertise of specialists in the substantive field to their task- such as environmental or health care- while prosecutors tend to be generalists. On the other hand, federal prosecutors, at least, increasingly coordinate cases with expert administrative colleagues. Coordination sometimes results in compliance and governance reforms appearing in the civil settlement rather than the DPA. Such reforms draw on agency guidelines in the relevant regulatory field-yet another difference with the more ad hoc quality that seems to characterize the DPA population. Even so, the analysis in this Article is intended to provide a useful general framework for DPAs pursued by all prosecutors, especially criminal (federal, state and local) but civil as wellpossible because of the emphasis on context throughout. See infra text accompanying note 197.

${ }^{76} \mathrm{~A}$ data base of federal corporate DPA s is maintained at the U niversity of V irginia, organized by Professor B randon Garrett. See http://lib.law.virginia.edu/Garrett/prosecution agreements.

${ }_{77}$ DPAs are also increasingly used to settle cases against individuals. Examples include the CEO of M onster Worldwide, who resolved a case against him using a DPA primarily because of unusual medical conditions he faced and Floyd Landis, an Olympic cycling star accused of doping, who created a legal defense fund that turned out to be based on misleading statements.

${ }^{78}$ See Samuel Rubenfeld, U.K. To Move Forward with Deferred Prosecution Agreements, WALL ST J. (Oct. 24, 2012).

${ }^{79}$ See Global Compliance Panel: Insights of Four Former Prosecutors, M etro. Corp. Counsel (A ugust 23, 2012).

${ }^{80}$ See J oseph W arin, Update on Corporate D eferred Prosecutions and Non-Prosecution Agreements, HARV. CORP. Gov. B LOG (July 26, 2012), available at https://blogs.law.harvard.edu/corpgov/2012/07/26/update-on-corporatedeferred-prosecution-and-non-prosecution-agreements/ ("M ore often than not, the narrative surrounding DPA $5 \ldots$ is negative").
} 
Critics have detected prosecutorial overreaching in certain cases. ${ }^{81}$ They say prosecutors impose terms on corporations rather than enter into good faith negotiations resulting in a voluntary or more tailored agreement. Critics have inferred this from the inclusion of peculiar terms, such as requiring donations to be made to causes with which a prosecutor may have a connection. ${ }^{82}$ Others stress that there is simply no objective basis for determining whether DPAs are effective or their net costs and benefits. ${ }^{83} \mathrm{~A}$ broader critique questions the competence of prosecutors to propose or negotiate certain terms commonly used in DPAs, which extend from enhanced internal corporate procedures concerning compliance to personnel changes and other top-level governance mandates. ${ }^{84}$

Several rationales, however, support DPAs. Rationales include avoiding the risk of adverse collateral consequences of corporate convictions- the so-called A ndersen effect. From the perspective of economic theory, the adverse collateral consequences are essentially negative externalities, and DPAs are designed to avoid those. On the upside, DPAs are designed to achieve positive externalities, which arise from their production of general deterrence. DPAs may be valuable alternatives to criminal convictions or civil regulation when investigations generate firm-specific information about corporate defects that the agreements can cure. Finally, both sides may find such a settlement appealing simply to avoid the cost and uncertainty of a trial. $^{85}$

\section{Andersen's Seminal Lesson}

A new line of criticism is emerging to challenge the lessons that have been taken from the Andersen case. The extensive literature routinely repeats that the lesson of Andersen is that prosecutors should try earnestly to avoid indicting large business organizations because of the risk of the collateral consequences for innocent people. ${ }^{86}$ Prosecutors embraced the point, as the frequency of prosecution, especially of large business organizations, declined. ${ }^{87}$ However, this "Andersen effect" is not necessarily a valid lesson of Andersen or the most important.

On the contrary, empirical evidence accumulated since Andersen demonstrates that corporations and other businesses rarely collapse from indictments or face other serious collateral consequences. For example, recent research identified several dozen indictments of large public corporations in the past decade; only a handful of the firms failed and the indictment

\footnotetext{
${ }^{81}$ Peter Spivack \& Sujit Raman, Regulating the "New Regulators": Current Trends in Deferred Prosecution Agreements, 45 A M. CRIM. L. REV. 159, 186 (2008); M iriam Hechler Baer, Insuring Corporate Crime, 83 IND. L.J . 1035, 1044-71 (2008); Jennifer Arlen, Removing Prosecutors from the Boardroom, supra note 3; Rachel Barkow, The Prosecutor as Regulatory Agency, in PROSECUTORS IN THE B OARDROOM, supra note 1.

82 Such criticisms can seem overstated, as discussed in Section IV .B, infra.

${ }^{83}$ K athleen Boozang \& Simone Handler-Hutchinson, 'M onitoring' Corporate Corruption: DOJ 's U se of Deferred Prosecution Agreements, 35 A M. J. L. \& M ED. 89 (2009); U.S. GoV'T A CCOUNTABILITY OFFICE, GA 0-10-110, D0J has Taken Steps to Better Track Its USe of Deferred and Non-Prosecution A greements, But Should Evaluate EfFECTIVEnESS 25 (2009). Legislators have taken heed, with bills in Congress proposing standards to govern DPAs and promote prosecutorial accountability. E.g., H.R. 1947.

${ }^{84}$ See J ennifer Arlen, Removing Prosecutors from the Boardroom, in PROSECUTORS IN THE BOARDROOM, supra note 1. Such objections and others are evaluated in Section III.C, infra

${ }^{85}$ For additional references to possible rationales for DPAs, see infra text accompanying note 214.

${ }^{86}$ See sources cited supra note 73.

${ }^{87}$ See B randon L. Garrett, G lobalized Corporate Prosecutions, 97 V A. L. Rev. 1775 (2011).
} 
was not necessarily the cause. ${ }^{88}$ Even iconic firms such as Steve Madden's shoe company and $M$ artha Stewart's lifestyles business survived criminal convictions of those people. As a matter of theory, moreover, there is reason to doubt whether such collateral risks are a sufficient justification for DPAs as opposed to indictment and prosecution. ${ }^{89}$

0 verlooked Governance. To add a new perspective to this literature, a more important lesson of Andersen is how prosecutors failed to assess or understand the firm's governance, thereby causing its collapse. A ndersen's salient governance features were those associated with its form, ownership and management. A ndersen was a partnership. Its members owned the firm and managed it. $M$ any thus had considerable human and financial capital tied to the firm. Threats to the firm's survival from an indictment could be expected to induce partner withdrawals, including flights to peer firms, fueling a self-fulfilling spiral. ${ }^{90}$

In contrast, had A ndersen been a corporation, owned by diversified outside shareholders and managed by professional directors and hired officers, a different prediction would have been warranted. Such groups would have been less dependent on the firm than the partners were and thus better able and willing to bear the risk of staying the course. Despite the salient features of A ndersen's governance, however-a partnership owned and managed by its members - the warnings of an "Andersen effect" that stoked prosecutorial allergies to organizational indictments spoke of the danger indictments pose for large corporations. ${ }^{9}$

As for clients, other aspects of Arthur A ndersen's governance, broadly defined, come into play. An indictment would prompt federal regulators at the SEC to threaten to debar the firm's authority to audit SEC registrants. Even private clients, not needing such SEC approval, valued Andersen as a partnership of professional accountants and its related reputation that the indictment threatened. A $n$ indictment of such a firm thus seems relatively likely to precipitate defection, by clients and partners alike. Collateral consequences, ultimately destroying the firm, were grave for the firm's vast employee base, innocent of wrongdoing, as well as clients needing to scramble to retain other auditors.

Governance Matters. The exact risks of indictment and probabilities of adverse collateral consequences cannot be gauged definitively. $Y$ et the question of adverse collateral consequences - which DOJ guidelines since Andersen direct prosecutors to study ${ }^{92}$ - requires an examination of governance features. That is the only way to determine whether the fallout from indictment will hurt innocent parties who warrant protection-and not every employee or

\footnotetext{
${ }^{88}$ See Gabriel Markoff, Arthur Andersen and the Myth of the Corporate Death Penalty: Corporate Criminal Convictions in the Twenty-First Century (draft manuscript 2012 available at http://papers.ssrn.com/abstract $i d=2132242$ ) (identifying 51 companies, though a review of the list suggests need to add and subtract a few, in part to verify which were public at the time of prosecution and conviction and in part to address the exact posture of the case in terms of criminal procedure). The companies that reportedly failed were Utilicorp U nited, W inn Dixie, Elpida M emory, and Japan International Airlines- and two of those failed businesses were nevertheless later taken over and rehabilitated to some extent by other companies. Id. A mong companies indicted without subsequent failure were several global airlines (for antitrust violations); Chiquita B rands (for terrorist financing violations); and Eli Lilly (for selling misbranded drugs). Id.

${ }^{89}$ See Jennifer Arlen \& M arcel Kahan, Corporate Governance Regulation Through Non-Prosecution (draft manuscript 2012 on file with the author and cited with permission) (explaining how the concept of asset insufficiency in the economic theory of regulation cannot justify DPA s containing ex post regulatory terms).

${ }_{90}$ See J onathan Macey \& Hilary A. Sale, Observations on the Role of Commodification, Independence, Governance, and the Demise of the Auditing Profession, 48 V ILLAN OVA L. ReV. 1167 (2003).

${ }^{91}$ See sources cited supra note 73.

${ }^{92}$ See sources cited supra note 68.
} 
shareholder group can claim such innocence. The DOJ's solicitude for such groups is unusual within criminal law, ${ }^{93}$ which ordinarily offers at most pity to the family and associates of defendants. ${ }^{94}$ The DOJ cannot intend its collateral consequences principle to protect such groups unless they are deemed innocent, and assessing such a question ex ante requires considering target governance.

A mong corporations, distinctions must be drawn between publicly-held and closely-held firms. These may imply different owner attitudes towards firm wrongdoing and managerial capacity for it, probative of the degree to which collateral consequences of indictment or prosecution should be seen as adverse or not. The separation of ownership from control is starker in the case of a large public corporation, such as A rcher Daniels $\mathrm{M}$ idland, where shareholders as a group should be seen as relatively more worthy of protection than shareholders of an equally large non-public corporation, such as Cargill, where ownership is concentrated in the hands of a single family. Such differences warrant predicting different reactions to different forms of prosecutorial pressure and different perceptions of what constitute adverse collateral consequences.

A mong publicly-held corporations, distinctions and related predictions can be drawn on the basis of such potentially relevant factors as the level and type of shareholder ownership and its bearing on questions of collective action and rational apathy. The more concentrated the ownership in fewer hands, and the larger the institutional ownership level, the easier collective action becomes. Institutional investors should not al ways be seen as innocent victims but, given activism and power, be held accountable too. ${ }^{95}$

A gain, the type of institutional owner matters along with the size of holdings. W al-M art, for instance, is owned $48 \%$ by family-controlled Walton Enterprises, an ownership position that may entail responsibility for criminal conduct at the firm. A shareholder's investment purpose may provide prima facie clues about relative cul pability or innocence, with long-term investment outlooks warranting greater respect potentially than short-term arbitrage positions. ${ }^{96}$ Similarly, some investors concentrate investment in a relatively smaller number of firms that enable close watch and disproportionate gains. ${ }^{97}$ Other investors, such as index funds, diversify greatly and should not be expected to provide similar monitoring and do not benefit as extensively from wrongdoing. ${ }^{98}$

\footnotetext{
${ }^{93}$ See Darryl K. Brown, Third-Party Interests in Criminal Law, 80 TEX. L. REV. 1383 (2002).

${ }^{94}$ See Susan Hoffman Fishman, The Impact of Incarceration on Children of Offenders, $15 \mathrm{~J}$. CHILDREN CONTEM P. SOC'Y 89 (1993).

${ }^{95}$ See Imam Abnbtawi \& Lynn Stout, Fiduciary Duties for Activist Shareholders, 60 STAN. L. ReV. 1255 (2008); A my J. Sepinwall, Guilty By Proxy: Expanding the Boundaries of Responsibility in the F ace of Corporate Crime, 63 HASTINGS L. J. 411 (2012); see also Lisa M. Fairfax, On the Sufficiency of Corporate Regulation as an Alternative to Corporate Criminal Liability, 41 STETSON L. REV. 118, 124 (2011).

${ }^{96}$ See Lynne L. Dallas, Short-Termism, The Financial Crisis, and Corporate Governance, 37 J. CoRP. L. 265 (2012).

${ }^{97}$ Examples: State Street Corp., which owns 12\% of United Technologies; B erkshire Hathaway which owns 8\% of W ells Fargo; and Davis Selected A dvisors, which owns 5\% of CVS Caremark. (This and accompanying footnote examples are drawn from a data set the author is compiling with assistance from N icholas Stark.)

${ }^{98}$ The best example is $\vee$ anguard, an index investor barely audible among the activist investor crowd, and owner of just under $5 \%$ of many of the largest A merican companies. A mong the Fortune $50, \mathrm{~V}$ anguard owns just under $5 \%$ of the voting stock of Exxon Mobil, Conoco Phillips, General Electric, AT\&T, Bank of A merica, Verizon, J.P. M organ, Citigroup, Procter \& Gamble, A rcher Daniels M idland, B oeing and Pfizer.
} 
A mong all corporations, those with higher degrees of insider ownership-by directors, officers and employees - may respond differently and require different treatment than those with little or no such ownership. In corporations that have substantial employee ownership, as through employee stock ownership plans, the roles of employee and shareholder combine, so that any gains from criminal conduct that might accrue to shareholders are enjoyed by those participating employees. ${ }^{99}$ Shareholders owning substantial percentages of a corporation's stock may indeed be victims when senior management commit crimes but their ability to elect the board who appoints such officers negates the claim to innocent victimhood. ${ }^{100}$

Besides such factors as type of business organization and shareholder demographics, prosecutors should consider additional governance details about targets. The most obvious concerns the special treatment required concerning businesses owned by other organizationssuch as subsidiaries of corporate parents. Evaluating probable culpability and likely collateral consequences require gauging the norms of governance in such settings and evaluating the degree to which they are followed. ${ }^{101}$

Every governance situation differs somewhat. Prosecutors must therefore follow through with kindred profiles at target firms specifically researching directors, officers, gatekeepers, employees and controls. That said, as a further illustration, the next Part's case study of AIG begins with a thumbnail sketch of its governance. Prosecutors would have done well to consider it when targeting AIG and settling using a DPA. Their failure to do so proved disastrous.

\section{AIG, OVERSIGHT AND INATTENTION}

This Part, an original case study of AIG ${ }^{102}$ first introduces A IG by canvassing some of its distinctive governance features illustrating the kind of profile useful for prosecutors to understand at the outset of investigation. ${ }^{103}$ It then explains how ignoring or disrespecting those

\footnotetext{
${ }^{99}$ Employee ownership levels vary among the largest U.S. corporations. A mong the greatest percentage levels are $M$ et Life (8\%) and Ford M otor (7\%).

${ }^{100}$ To take some examples from among the Fortune 500 in the U nited States: W arren B uffett of Berkshire H athaway (38\%); M ichael Dell of Dell (16\%); Charles Schwab of Schwab (14\%); Stephen W ynn of Wynn Resorts (10\%); and William Gates of M icrosoft (5.5\%).

${ }^{101}$ For a good discussion of the kinds of factors relevant in such a setting, by non-experts demonstrating the possibility of mastering such terrain, see U nited States v. B est-F oods, 524 U.S. 51 (1998).

${ }^{102}$ M uch has been written about AIG's role in the financial crisis of 2008 , though much of that concentrates on the terms of related financial transactions rather than the governance history leading up to their creation. See, e.g., Richard Squire, Shareholder Opportunism in a World of Risky Debt, 123 HARV. L. REV. 1151 (2010); William K. Sjostrom, Jr., The AIG Bailout, 66 W ASH. \& LEE L. REV. 943 (2009).

${ }^{103}$ The A IG case study can seem aberrational, given the characters involved, peculiar features of N ew $\mathrm{Y}$ ork law and politics, and the timing of events. But, in addition to remaining a bracing cautionary tale worth telling and mining for lessons, the potential for a replay should not be discounted. Similar controversy recurs about the exercise of prosecutorial authority and the independent streak of $\mathrm{New} \mathrm{Y}$ ork law enforcement authorities. One instance arose when New Y ork's Department of Financial Services, headed by Benjamin Lawsky, settled charges of terrorismfinance law violations against Standard Chartered, the B ritish bank, while federal authorities pursued a parallel investigation. See J essica Silver-Greenberg, Standard Chartered Settles Iran Inquiry for $\$ 340$ M illion, N.Y. TIM ES (A ug. 14, 2012). Some stories drew explicit analogies between the two chief prosecutors involved (Eliot Spitzer in AIG and B enjamin Lawsky in Standard Chartered). See J essica Silver-Greenberg, Regulator Shines a Spotlight on a Bank, and on Himself, N.Y. TIMES (A ug. 10, 2012). More generally, federal prosecutors' offices vary from many state counterparts, such as those in New Y ork, where the attorney general's office holds both prosecutorial and regulatory responsibilities and pursues both civil and criminal cases arising from the same circumstances. Federal
} 
governance realities resulted in a hasty and costly upheaval that included ousting the company's iconic CEO, M aurice R. ("Hank") Greenberg. It shows how that failure to investigate before intervening came at a high price with the subsequent discovery of only limited transgressions not warranting the ouster decision-let alone an indictment. Finally, it shows the perils of conceiving of corporate governance as a uniform set of off-the-rack devices with no articulated rationale as new governance at AIG led the company to the center of the 2008 financial crisis. The basis for two prescriptions emerges: prosecutors should strive to understand corporate governance when exercising discretion concerning prosecutions of business targets and should articulate the rationales of governance reforms they proffer when settling cases using DPA s. ${ }^{104}$

\section{A. AIG's G overnance Profile}

A profile of AIG's corporate governance highlights factors prosecutors need to understand when targeting a business organization. Such attributes are important to grasp as they reflect the inner workings and mechanisms of a company. Along with the personnel involved, they are what makes the company tick. In this case, readily discernible matters included a nimble, innovative, employee driven culture with global reach; a diverse shareholder mix that included heavy insider ownership, considerable retail ownership and a mix of passive and activist institutional shareholders; deep and longstanding internal control systems; and a fractious board members debating executive succession planning. A rudimentary grasp of such examples of a corporate persona would greatly assist a prosecutor looking to formulate a profile to help make decisions about whether to charge a company or individuals and whether to proceed with an indictment and prosecution or settle- and on what terms.

Scale. AIG's foundations were domestic insurance operations assembled in the 1960 s by Greenberg, along with a collection of international insurance businesses created during the previous five decades by the A merican international business pioneer, Cornelius $V$ ander Starr. From 1969 when AIG went public to 2004, the total market value of AIG's stock rose from $\$ 300$ million to $\$ 180$ billion - an increase of approximately $19,000 \%$ compared to a $700 \%$ increase in the S\&P 500. ${ }^{105}$ By then, AIG employed 92,000 , earned more than $\$ 11$ billion annually and commanded total assets approaching $\$ 1$ trillion. It was the largest insurance company in world history.

prosecutors invariably cooperate and coordinate with regulatory counterparts, supra note 75 , while Spitzer, at least, often disrespected federal agencies. See Jonathan R. Macey, State-F ederal Relations Post-Eliot Spitzer, 70 BROOKLYN L. REV. 117 (2004).

${ }^{104}$ The case study arose out of my collaboration on a book with Greenberg. M AURICE R. GREENBERG \& LAWRENCE A. CUNNINGHAM, THE AIG STORY (2013). It is based on my original research into extant public materials, as well as considerable non-public materials, including documents obtained under N ew Y ork State's Freedom of Information Law (FOIL), and interviews with many participants. Some of those interviewed requested anonymity; some requests for interviews were declined. The result is an imperfect record of events, offering the benefits, along with the limits, of case studies as a research method. See ROBERT K. Y IN, CASE STUdY RESEARCH: DESIGN AND METHOdS $\left(4^{\text {th }}\right.$ ed. 2008). Single-event case studies must be interpreted cautiously and lessons drawn narrowly to avoid incorrect causal explanations. See Gregory Mitchell, Case Studies, Counterfactuals, and Causal Explanations, 152 U. PA. L. REV. 1517 (2004); see also supra note 103 (acknowledging AIG case as potentially sui generis but how its high stakes and possible repetition warrant studying it). In this instance, the case study is supplemented by analysis and examples elsewhere in this Article and is sufficiently reliable to support the two prescriptions noted.

${ }^{105}$ See C. J. Prince, CEO of the Year 2003, CEO M A GAZINE (J uly 1, 2003). 
Innovative Internationalists. AIG's culture valued product innovation. The company pioneered insurance covering armies, kidnapping, oil pipelines and rigs, satellites, shipping, and other unusual risks, helping A merican companies expand internationally in the process that evolved into globalization. In addition, despite its size, A IG fostered this innovation by creating mechanisms within the company that could quickly respond to a need for new products ${ }^{106}$ even if the need was on the other side of the world. ${ }^{107}$ Decades before globalization, A IG opened markets not only in Mao's China but also behind the Iron Curtain in the Soviet Union and its Eastern European satellites during the Cold War; and in Japan, M alaysia, the Philippines and throughout Latin A merica, the M iddle E ast and A frica. ${ }^{108}$

Employees. A IG's management cultivated an employee-centric atmosphere, by stressing mutual loyalty, never leaving any employee behind, whether navigating treachery abroad or facing personal crises at home. A distinguished cohort among A IG employees were the "mobile overseas persons" or M.O.P.S. This group did service stints in numerous countries during their career, as many as 10 to 15 , taking two-to-three year terms in each place. A kin to the U.S. foreign service, they were corporate ambassadors who could troubleshoot the thorniest problem anywhere in the world.

Employee compensation was long-term, with most payoffs deferred until age 65 . In the corporate restructurings that occurred to take AIG public, one company (Starr International $\mathrm{Co}$., abbreviated $\mathrm{SICO}$ ) that contributed assets to AIG also received shares of its stock. ${ }^{109} \mathrm{~A}$ small group of Starr's closest business associates, including Greenberg, owned all the SICO stock, entitling them to all the AIG shares received in exchange. They decided instead to preserve a portion of the AIG shares for SICO's future corporate use. A n important use, made over the next three decades, was providing incentive compensation to AIG managers paid in AIG shares. The

106 A IG led the charge to change the world's view of service industries. International trade conventions had long covered trade in goods, but countries discriminated against service providers, such as AIG. B eginning in the late 1970s and early 1980s, the company led efforts by scores of other companies and successive U.S. Trade Representatives, from the Carter to the Clinton administrations, finally winning in 1997's W orld Trade Organization financial services agreement. $M$ any scholars and policy analysts contributed independent research that reached the same conclusions about the value of trade in services globally. E.g., GEZA FEKETEKUTY, INTERNATIONAL TRADE IN SERVICES: A N OVERVIEW AND BLUEPRINT FOR NEGOTIATIONS (1988); Jagdish N. Bhagwari, Trade in Services and the Multilateral Trade Negotiations, 1 WORLd BANK ECON. Rev. 549 (1987); RONALD K. SHELP, BeyOND Industrialization: Ascendancy of the Global Service Economy (1981) (Shelp was an Aig government relations employee).

${ }^{107}$ For example, AIG was among the first substantial A merican companies to do business in China in the $20^{\text {th }}$ century. Starr's businesses, founded in China in 1919, were ousted along with all other foreign companies in 1949 amid its civil war, which was followed by the nation's isolation for several decades. A fter the thawing of China-U.S. relations in 1972, Greenberg undertook an arduous process that spanned through 1992. The result: AIG was the first foreign insurance company licensed by China in the modern period and among the first large foreign companies to resume business there. See David M. Lampton, Same Bed Different Dreams: Managing U.S.-China RELATIONS 1989-2000 348-352 (2001).

${ }^{108}$ As AIG grew into a leading A merican international insurance company, its interests and activities became increasingly intertwined with those of the United States. For example, it insured equipment used in national intelligence gathering exercises and military commitments. More broadly, AIG fought for open trade in dozens of countries and in several important global trade negotiations alongside U.S. trade negotiators. It joined forces with the U nited States government in numerous episodes promoting democracy and capitalism, in the Soviet U nion, I ran, Korea, Nigeria, Peru and $\mathrm{V}$ ietnam - to name a few.

${ }^{109}$ See SICO v. AIG, 648 F.Supp.2d 546 (S.D.N.Y. 2009). 
incentives were long-term: awards were made annually based on the previous two years' performance but shares did not vest until age $65 .{ }^{110}$

AIG did not enter into employment contracts with any employee, from the CEO to underwriter trainees, as these were not considered necessary for employee security or desirable from an incentives perspective. V aluing experience highly, A IG eschewed mandatory retirement for employees and many employees, including senior management, worked into their $70 \mathrm{~s}$ and 80 s.

Shareholders. M any AIG employees were also shareholders with large portions of their net worth in AIG stock. SICO continued to own a large percentage of AIG's stock, declining as AIG grew, through share transfers and dilution, reaching $12 \%$ as of 2005 . AIG's other management-directors owned or controlled substantial shares and the company earned a reputation as a "core stock holding" for many portfolios, including state pension funds and those of the proverbial "widows and orphans." ${ }^{111}$ AIG's size- a market capitalization reaching $\$ 180$ billion-made it a choice target of institutional investors in the corporate governance movement, particularly during the push to enable shareholders to nominate directors (the proxy access movement). ${ }^{112}$

Controls. AIG developed sophisticated systems of internal control. These dated to the 1970s when global operations demanded aggregating financial and insurance information arising from millions of transactions annually in more than 100 countries. AIG established an audit committee, led by the board members and staffed by senior accounting officials. They divided A IG's operational world into 30 reporting regions, appointed controllers of each, and established foreign and domestic internal auditors to oversee everything. By 1984, AIG won a A A credit rating, which enabled it to diversify earnings by expanding into a few other fields besides insurance. AIG moved into private equity, aircraft leasing, global infrastructure funds and financial products. The latter, called the FP division, required adding even more elaborate internal controls because it managed an investment portfolio not subject to maintaining liability reserves like that of insurance companies must. Several distinct internal groups, as well as the outside auditor, consistently monitored FP's risk portfolio. Risk management was part of AIG's corporate DNA. ${ }^{113}$

\footnotetext{
${ }^{110}$ The SICO-funded AIG compensation plan had some kinship to Employee Stock O wnership Plans that were being developed in the same period by Louis Kelso. See LOUIS KELSO \& MORTIMER J. ADLER, THE CAPITALIST Manifesto (1958); LOUIS Kelso \& Patricia HetTer Kelso, Dem OCRACY and ECONOMIC POWER: Extending THE ESOP REV OLUTION ThroUgh BINARY ECONOMICS (1986); see A ndrew W. Stumpff, F ifty Years of U topia, TAX LAWYER 62 (2009): 419 (noting how ESOPs gained momentum after passage of 1974's Employee Retirement Income Security Act, ERISA, which provided favorable tax treatment).

${ }^{111}$ See Roddy B oyd, Fatal Risk: A Cautionary Tale of A IG's Corporate Suicide 45 (2011).

${ }^{112}$ See AF SCM E v. AIG , 452 F.3d 121 ( $2^{\text {nd }} C$ Cir. 2006).

${ }^{113} \mathrm{~N}$ evertheless, even the most rigorous internal controls can be porous as AIG discovered in two instances during the period following Enron and Sarbanes-Oxley. In one, a junior manager at a small AIG subsidiary wrote a policy that apparently enabled another party, a small telecom supplier called B rightpoint, to manipulate its financial results. The SEC threatened suit but AIG settled the case for $\$ 10$ million and allowing an SEC-designated monitor to roam around AIG's other subsidiaries in search of any similar problems, which did not appear to exist. See SEC V. AIG, Litigation Release No. 18,340 (Sept. 11, 2003). In the second case, the SEC and the DOJ asserted that the company's FP division aided violation of accounting rules by PNC Bank when providing asset management services. This was settled using a deferred prosecution agreement that called for a monitor to assure that FP did not offer products that other parties could use to manipulate accounting records, along with payment of $\$ 126$ million. See SEC v. AIG, Litigation Release N o. 18,985 (Nov. 30, 2004); DOJ-AIGFP DPA (N ov. 30, 2004). This monitor's
} 
Directors. A IG's founding corporate board in 1967 included the luminaries who would spend their careers making it the world's largest insurance company. Traditional inside directors, they knew the company and the insurance business well and were world travelers who understood the demands of building a global financial services company. From 1984, when AIG listed on the NYSE, stock exchange rules, federal securities law, state court rulings, and institutional investor advocacy all gradually required or induced A IG to add increasing numbers of outside directors. ${ }^{114}$ By the early 2000s, outside directors comprised a majority of AIG's board, which created a culture in which outside directors were newly inspired to challenge insiders. The traditional mutually supportive and respectful relationship among board members frayed.

Succession. During the early 2000s, part of AIG's corporate objectives included planning for succession. Succession is a challenging process for many corporations, particularly one in which the leader invested his career and identity in it, as G reenberg had in A IG. ${ }^{115}$ Nevertheless, AIG's board and Greenberg wrestled with it beginning in 2000, when Greenberg was 75 . They narrowed the potential successors down to two senior managers- both in their early 50s. As of late 2004, an understanding was reached among Greenberg and the board, that one of those two would become CEO for a trial period beginning as of the company's annual meeting in J une 2005, while G reenberg remained chairman. Despite the arrangement, some directors worried that such a transition would result in Greenberg, a formidable figure, overshadowing the CEO-elect. A faction of outside directors even retained special counsel to advise them on succession. Conversations were continuing in early 2005 when prosecutors began a probe at A IG.

\section{B. Ex Ante Miscalculation}

The 2005 probe into AIG was started by Eliot L. Spitzer, attorney general of New Y ork. Spitzer made a name for himself investigating prominent companies and people and became famous for controversial tactics and disrespecting corporate governance realities. ${ }^{116}$ For instance, in 2004, Spitzer aimed at insurance brokers for bid-rigging, filing a civil case against $M$ arsh \& M CLennan. He threatened criminal charges against the firm as a bludgeon, to induce its board's cooperation in seeking the resignation of its CEO. Spitzer declared that he would not negotiate with M arsh's board while the incumbent remained chief executive, forcing his resignation. ${ }^{117}$ Spitzer's ultimatum overstepped prosecutorial bounds into the real $\mathrm{m}$ of corporate governance.

Intervention. In February 2005, Spitzer targeted AIG and Greenberg. ${ }^{118}$ Some of A IG's outside directors were concerned about corporate liability or personal liability, while one faction riveted on succession. That faction relied heavily on the lawyer they had retained four months

\footnotetext{
performance would prove dismal during these years leading to the financial crisis of 2008 in which AIG played a central role. See infra text accompanying notes 265-268.

${ }^{114}$ See J oseph B. Treaster, Some A.I.G. Shareholders to Press for More Independent Board, N.Y. TIMES (M ay 15, 2000); J oseph B. Treaster, A.I.G. H ead Will Consider Altering Board, N.Y. TIM ES (M ay 18, 2000).

${ }^{115}$ See Tom C.W. Lin, The Corporate Governance of I conic Executives, 87 N OTRE DAM E L. ReV. 351 (2011).

${ }^{116}$ See, e.g., Kulbir W alha \& Edward E. Filusch, N ote, Eliot Spitzer: A Crusader Against Corporate M alfeasance or a Politically Ambitious Spotlight Hound: A Case Study of Eliot Spitzer and Marsh \& McLennan,18 GEO. J. LEGAL ETHICS 1111 (2005).

${ }^{117}$ See J oseph B. Treaster, Broker Accused of Rigging Bids for Insurance, N.Y. TIM ES (October 15, 2004).

118 See Brooke A. Masters, Spoiling for a Fight: The Rise of Eliot Spitzer 239 (2006); Peter Elkind, ROUGH JUSTICE: THE RISE ANd FALL OF ELIOT SPITZER 84-85 (2010).
} 
earlier. These directors and their lawyer became not merely cooperative, but aligned with Spitzer. There is no clear record about exactly why they did so, but it shifted the governance machinery in favor of a more rapid and complete succession than had been agreed.

Through early March, AIG's auditor was prepared to sign off on the company's 2004 financial statements. But it soon made a turnabout, again for reasons that are not clear except that it faced extraordinary pressure-either from the outside director faction, lawyers or prosecutors-amid great sensitivity given Andersen's recent collapse. Spitzer raised questions about AIG's accounting for a transaction it had made in 2000 with a large reinsurance company called $\mathrm{Gen} \mathrm{Re}$, then notorious for engaging in aggressive reinsurance deals with many other insurance companies. Though this one with AIG proved trivial as the saga played out over the next seven years, Spitzer's questions became ominous threats that drove AIG's corporate governance.

On Sunday March 13, before an investigation had been done, AIG's outside directors held a special meeting. They debated the risks to AIG of a corporate indictment, shared concerns about personal liability and addressed the pending succession issue. A that meeting, the auditors dropped a bombshell, saying they would not certify the 2004 financials unless the board got $\mathrm{G}$ reenberg to resign. A side from not having done any investigation, the auditors clearly crossed a line with such a threat.

Spitzer had issued a subpoena requesting Greenberg to testify about Gen Re and other unspecified matters. AIG's employment manuals called for employees to cooperate in any investigation. Such cooperation commitments are now common in corporate employment manuals, prompted by the credit for cooperation corporations are given under the OSGs and DOJ practice. One director asked whether Greenberg would answer all of Spitzer's questions or take the Fifth. G reenberg explained that Spitzer refused to show him documents or limit the scope of questioning so that his lawyers adamantly advised taking the Fifth, though he had nothing to hide. ${ }^{119}$ Some directors seemed to believe that taking the Fifth would violate AIG's employment manuals, although as a legal and prudential matter such a conclusion is of uncertain validity. ${ }^{120}$

At the end of the lengthy meeting, the directors asked Greenberg to resign. M otives were mixed, however, since no investigation had been made; the decision was taken in the context of ongoing negotiations over succession; the auditors exerted unorthodox pressure; and no one knew whether taking the Fifth violated company policy in these circumstances. This was a manifestation of prosecutorial prerogative conjoined to a new model of corporate governance in which power had been reposed in outside directors advised by outside counsel and supported by outside auditors. It showed how the prosecutorial power met a corporate governance struggle that the prosecutor did not seem to understand.

Investigation. After the prosecutorial intervention in $\mathrm{March}$, an investigation was conducted during A pril, May and J une by AIG's auditors and outside counsel. They restated AIG's accounting for the previous five years, though the auditor had certified them during that

\footnotetext{
119 A witness recounting the same events more than once rarely does so exactly and two witnesses recounting events to a prosecutor often contradict each other. Either such common pitfall exposes a witness under oath to charges of perjury or obstruction of justice. Andrew Countryman, AIG Chief to Take 5th in Spitzer Interview: A Wise Decision, Say Several Legal Experts, CHI. TRIB. (A pril 12, 2005).

${ }^{120} \mathrm{Cf}$. U nited States v. Stein, $541 \mathrm{~F} .3 \mathrm{~d} 130\left(2^{\text {nd }} \mathrm{Cir}\right.$. 2008) (endorsing employee objection, on constitutional grounds concerning right to counsel and due process, to prosecutorial insistence that corporation refuse to cover legal defense expenses for any employee pleading the Fifth).
} 
time. ${ }^{121}$ The firms reported regularly to Spitzer, going beyond ordinary cooperation to the point of aligning their interests with those of Spitzer. ${ }^{122}$ The changes cut shareholders' equity, cumulatively across five years, by $2.7 \%$ in total and net income by $2.1 \%$ per year. ${ }^{123} \mathrm{~A}$ longstanding rule of thumb in corporate accounting treated variations of less than $5 \%$ as immaterial. A Ithough the SEC abrogated that custom in 1999, ${ }^{124}$ auditors signed off on reports so long as they were within $5 \%$ of their calculations of a fair financial picture, as AIG's were. The changes, moreover, congregated in areas where there had been controversy about the proper accounting for certain types of transactions and which auditors had debated for years. ${ }^{125}$

The restatement did not provide "probable cause" for a criminal case, which was never filed against Greenberg or AIG. ${ }^{126}$ Spitzer filed a civil case against Greenberg, under $\mathrm{New}$ Y ork's M artin A ct, initially based on seven changes reflected in the restatement. He eventually dropped all claims except for the Gen Re matter and one other issue in a case that continues unresolved today more than seven years later. ${ }^{127} \mathrm{~N}$ or did the restatement vindicate the decision to seek Greenberg's resignation - if it defined the threshold for determining to oust a CEO, few CEOs of large public corporations would remain in office for long.

$\mathrm{N}$ evertheless, the restatement, al ong with Greenberg's resignation, caused the company's stock price to drop dramatically and rating agencies to slash its AAA rating. Immediate direct costs to shareholders exceeded several billion dollars - an amount greater than the restatement and punishment to shareholders that suggested prosecutorial confusion about corporate governance. Worse, AIG settled with Spitzer and other government authorities under a DPA that

\footnotetext{
${ }^{121}$ A ccounting restatements became so common during the mid-2000s, that officials cautioned about restatements that were themselves suspect. E.g., J ohn W hite, SEC Director of the Division of Corporation Finance, Corporation Finance, A Focus on Financial Reporting (San Diego, 2008), pp. 5-6 available at www.sec.gov/news/speech/2008/spch012308jww.htm (commenting on concern and proposals made by an SEC Advisory Committee); see also Marlene Plumlee \& Teri Lombardi Y ohn, An A nalysis of the Underlying Causes A ttributed to Restatements (J une 2009) (noting mushrooming in number of restatements during this period, up from 475 in 2003 to 1,538 in 2006).

${ }^{122}$ See Ian M CD onald \& Theo Francis, Spitzer Expects a Civil Settlement with AIG, W ALL ST. J. (A pril 5, 2005).

${ }^{123}$ The raw dollar amounts were large but A IG was a massive company: equity changed $\$ 2.26$ billion and income $\$ 4$ billion (for the whole period), but AIG owned $\$ 800$ billion in assets and earned $\$ 11$ billion annually.

${ }^{124}$ See SEC, Staff A ccounting Bulletin N 0. 99 (A ug. 12, 1999).

125 Examples applicable to the insurance industry included accounting for finite insurance transactions and for liability reserves; examples applicable to all companies concerned topics such as accounting for equity-based compensation and for special purpose entities. A fter the restatement was released in $M$ ay 2005, Greenberg's lawyers and accountants spent the next two months examining every change made in it. Completed on July 26, 2005, their detailed memorandum challenged every change point-by-point.

${ }^{126}$ The only criminal charges arising out of the entire affair targeted one AIG employee and six Gen Re employees over the AIG-Gen Re transaction. The case resulted in early plea agreements by two Gen Re employees who became the government's star witnesses against the others. A fter seven years of litigation, which included a trial, appeal and order for a new trial, U nited States v. F erguson, 653 F.3d 61 ( $2^{\text {nd }}$ Cir. 2011), the case resulted in individual deferred prosecution agreements in which the defendants did not admit guilt. The appellate court characterized the testimony of one of the government's star witnesses as "not believable." Id. at 71.

${ }^{127}$ P eople v. Greenberg, N o. 401720/2005 (Sup. Ct. N.Y. M ay 2005). The N ew Y ork Court of A ppeals accepted the case to adjudicate the validity of the M artin Act, which Greenberg argues is preempted by federal securities laws. Under federal law and most state laws, proving business fraud requires "scienter," referring to a mental state evincing a deliberate intention to deceive, which does not purport to be a requirement under the Martin Act. See Steve A. Radom, Balkanization of Securities Regulation: The Case for Federal Preemption, 39 TEX. J. Bus. L. 295 (2003).
} 
would prove even more costly because of failure to relate its governance terms to AIG's governance realities.

\section{Ex Post Standardization}

A fter G reenberg's early resignation, while prosecutors continued to hold the threat of prosecution over the company's head, outside counsel negotiated governance reforms with Spitzer. ${ }^{128}$ Drafts of the agreement recited actions already taken, including Greenberg's resignation, and prescribed further changes. ${ }^{129}$ As part of these governance reforms, the board opted to separate the roles of the board chairman and CEO. Splitting the functions of CEO from board chairman had become fashionable, seen by many as a "best practice." It manifested the same rationale of prescriptions for adding outside directors, a desire to reduce the boardroom power of the CEO. At AIG, this separation had little to do with its prevailing governance realities, and contrasted sharply with the previous succession plan which, while entailing a separation of those functions, was tailored to the needs of the transition. As will be elaborated below, three years later, amid the financial crisis of 2008, it became clear that the separation of functions had failed and the board repealed it.

Off-the-Rack Governance. A pivotal clause in the Spitzer-AIG agreement required the board to hire a special advisor to identify additional outside director nominees and to prescribe "best practices" on "governance issues." ${ }^{130}$ That advisor, A rthur Levitt, a former SEC chairman, directed a list of reforms, all of which were standard terms he said were best practices and all of which AIG was required to adopt. ${ }^{131}$ Along with the ill-fated endorsement of splitting the identifies of the chairman and CEO, reforms called for adding even more outside directors; ${ }^{132}$ holding executive sessions of the board that excluded any management directors; eliminating the executive committee; imposing mandatory director retirement at age 73; and barring any former chief executive from serving on AIG's board. N one of these changes had anything particularly to do with AIG or its needs. In fact, Levitt chose his recommended reforms after consulting shareholder advocates, corporate governance experts and selected directors ${ }^{133}$ - but none of AIG's management, employees or largest shareholders.

\footnotetext{
${ }^{128}$ FOIL $09777011247-09777011262$.

${ }^{129}$ A IG entered into separate settlement agreements, with the DOJ, the SEC and N ew Y ork authorities. The DOJ DPA did not address governance reforms. AIG-DOJ DPA (Feb. 7, 2006), available at http://lib.law.virginia.edu/Garrett/prosecution_agreements/pdf/aig.pdf B ut both the SEC and N ew Y ork agreements contained numerous compliance and governance provisions and negotiated drafts of the $\mathrm{New} Y$ ork agreement recited more extensive governance provisions, most of which A IG enacted. FOIL 09777011247 - 09777011262.

${ }^{130} \mathrm{~N}$ ew Y ork - AIG DPA (July 2005). DPA s often require a company to hire a consultant to obtain input and agree to accept the directives or else file a request to reject the directives with the governmental authority. See infra text accompanying note 271 . The AIG DPA took such an approach.

131 A rthur Levitt, Letter to AIG B oard of Directors (M arch 21, 2006), reprinted in AIG 2006 Proxy Statement, available at http://www.sec.gov/Archives/edgar/data/5272/000095011706001641/a41737.htm, reprinted in GREENBERg \& CUNNINGHAM, THE AIG STORY, supra note 104.

132 The addition so many outside directors at AIG ultimately yielded a board with only two management directors out of a total of 17, depriving AIG's board of the expertise and company inside knowledge that had long been its hallmark. For criticism of this result, with reference to the ensuing financial crisis, see P.M. Vasudev, D efault Swaps and Director Oversight: Lessons from AIG , 35 J. CORP. L. 757 (2010).

${ }^{133}$ Levitt Governance Letter, supra note 131 ("we have canvassed the views of directors, shareholders, governance experts, and shareholder activists for recommendations").
} 
A telling mismatch between AIG's realities and Levitt's changes concerned abolishing the executive committee. Levitt supported that recommendation by saying that executive committees are "often a symbol of board cronyism." ${ }^{134}$ This general impression said nothing about the committee's quality or value at AIG. It had consisted of G reenberg and four outside directors, avoiding cronyism, and had a clear business rationale: to enable nimble operations in a dynamic global environment, reflected in A IG's entrepreneurial and international ist culture.

A nother ill-suited reform concerned age limits for directors. A IG's traditional employeecentric philosophy and its reliance on experienced mobile overseas personnel led it to embrace employees wishing to work beyond traditional retirement ages at other companies. People could retire at age 65 and many did, but a large number of AIG employees, including many in senior management and on the board, continued working well into their 70s or $80 \mathrm{~s}$. Greenberg, at the time of his forced resignation, was 79 . While age limits for directors were trendy during this period, with some $40 \%$ of Fortune 1000 companies adopting them in response to urgings from governance gurus such as CalPERS, they were an anomaly at AIG.

Controls. The Spitzer-AIG DPA prescribed and the board adopted a different set of committees, officers and reporting lines to handle matters of control and compliance. This approach put form of internal controls above substance, thereby threatening AIG's rigorous risk management. For example, controls at FP had been designed to assure that no transaction ever jeopardized AIG's A A A credit rating. A ll transactions were negotiated on the strength of that rating, which enabled it to assure counterparties of its ability to make good on its obligations at low cost, without posting collateral or pledging assets. Such controls kept the FP division from taking on too much risk and saddling the company with debts that would threaten A IG's insurance businesses.

E mployees. M ore tangible examples of AIG's transformation concerned the board's new practice of giving employment contracts to executives. No AIG employees had ever had employment contracts, from the CEO to underwriter trainees. Further, AIG adopted new bonus policies that moved from the long-term orientation of the employee compensation program run for three decades under Greenberg's stewardship toward short-term incentives, including at FP. ${ }^{135}$ All these corporate governance changes would change A IG, though not in the ways that prosecutors or executives would have hoped. Short term incentives, combined with slackened controls, would prove perilous.

Chaos. In A pril 2005, FP began writing credit default swaps on increasingly risky pools of mortgage related debt, called "subprime." ${ }^{136}$ During 2005, FP's portfolio steadily declined in quality; it started with a small fraction of subprime mortgage pools and became entirely subprime. ${ }^{137}$ By J une 2007, A IG had written $\$ 80$ billion of swaps on the riskiest mortgage pools, quintupling its

\footnotetext{
${ }^{134}$ Id.

135 Today's intense debates over executive compensation stress the value of incentives driven by long-term compared to short-term compensation, which AIG understood for decades before such debates. See Sanjai B haga \& Roberta Romano, Reforming Executive Compensation: Focusing and Committing to the Long Term, 23 YALE J. REG. 659 at n. 23 (2009).

${ }^{136}$ Credit default swaps are contracts in which a lender reduces its risk of exposure of loss due to borrower default by swapping that risk to another party, essentially an insurer, who bears that risk in exchange for a fee. Subprime pools of mortgage related doubt gathered loans taken by homebuyers with relatively poor credit histories. That increased the risk of default on any given loan; but those who sold pools of such loans sliced them into tranches with varying degrees of risk. FP backstopped the tranches that deal designers called "super senior," denoting that the risk of default was remote. In many cases, it appears that these firms misrepresented the quality of the pools- what AIG was told were "super senior" were the bottom of the barrel.

${ }^{137}$ M ICHAEL LEWIS, THE BIG SHORT 71-72 (2010).
} 
2005 position, all un-hedged. M any swaps required AIG to post cash collateral if AIG's credit rating fell or the value of covered contracts declined. Following industry practice, AIG subsidiaries historically lent securities to borrowers in exchange for cash collateral which would be invested in short-term/low-risk investments to gain modest interest. From 2006 through 2008, A IG greatly increased these stakes, taking longer-term, riskier assets, including mortgage backed securities. ${ }^{138}$

At the same time, a global financial crisis had been brewing due to a combination of forces that overheated real estate markets worldwide. ${ }^{139}$ During 2007, the U.S. housing market weakened, contributing to an intertwined series of economic problems that spread globally into a financial crisis. M ortgage-related assets began to decline in value. From mid-2007 to late 2008, these problems gathered momentum and amplified worldwide. AIG's liquidity problems began to emerge in J uly 2007 when customers requested it to post cash collateral amid the weakening market.

A IG faced a growing gap between its duty to return that cash collateral to counterparties and the fair value of the mortgage securities its insurance subsidiaries bought with it. ${ }^{140}$ The combination of this gap and the escalating collateral calls facing FP squeezed AIG's liquidity. But the mounting turmoil escaped the attention of AIG's senior management and board, as the company's internal controls failed. ${ }^{141}$ It was not until J une 2008 that AIG's board responded by asking the CEO to resign and the board chairman to assume the role of CEO as well-repudiating an important part of the governance reforms begun three years earlier. ${ }^{142}$ The repair efforts came too late, however, as the company sailed into the financial crisis to be taken over by the U.S. government in September 2008.

Causation, Correlation and Best Practices. One must ask the question of causation versus correlation: whether the governance changes were a cause of AIG's role in the crisis or merely correlated with it. ${ }^{143}$ Investigation and testimony point to the changes playing a causal

\footnotetext{
${ }^{138}$ Bethany M CLean \& J Oe n ocera, A ll the Devils are Here 328 (2011).

139 See generally Lawrence A. Cunningham \& David Zaring, The Three or Four Approaches to Financial Regulation: A Cautionary Analysis against Exuberance in Crisis Response, 78 GEO. WASH. L. REV. 39 (2009). Factors included: (1) U.S. policy overstimulated appetites for home ownership and kept interest rates low for too long; (2) regulation of financial institutions was poor, as commercial banks fed the appetite for home ownership with generous mortgages while investment banks churned demand with complex financial products and increasing leverage; (3) rating agencies failed to analyze many financial products adequately and the lack of trading in such products on organized markets made them difficult to value; and (4) regulators at the SEC failed to monitor the leverage of many financial institutions, whose debt levels rose to as much as 30-40 times capital and, in AIG's case, regulators at the Office of Thrift Supervision, which had authority because AIG owned a savings and loan association, simply ignored any signs of trouble.

${ }^{140}$ U.S. Government accountability Office, Review of the federal Reserve System financial ASSISTANCE TO AMERICAN INTERNATIONAL GROUP, INC. 5, 17 ( 2011).

${ }^{141}$ By February 2008, it had become clear to AIG's outside auditors that disaster was coming. It reported a chilling and pervasive problem at the new AIG: an appreciation of risk and risk management, once a defining trait of AIG, had been pushed out of its corporate culture. The auditor provided detailed and scathing criticism of AIG's top three executives. See GREENBERG \& CUNNINGHAM, supra note 104 (reprinting the auditor's notes).

${ }^{142}$ A IG Press Release, A IG Names R obert B. Willumstad Chief Executive $O$ fficer (J une 15, 2008).

${ }^{143} \mathrm{~A}$ stronger version of this inquiry asks whether, had Greenberg not been replaced, AIG's role in the crisis would have been diminished. $M$ any believe that the answer is yes, including leading insurance industry executives who knew AIG and Greenberg well enough to be in good positions to make a judgment. See M ichael Loney, 30 Years in Insurance: Learning the Hard Way, REACTIONS: EUROMONEY INST. INV. (A pril 1, 2011) (quoting John Byrne, former chairman of the insurance companies GEICO and Fireman's Fund).
} 
role. Forensic reports on the crisis blamed AIG's role in it on governance, risk management and internal control problems during 2007 and 2008. ${ }^{144}$ Testimonial evidence, from AIG's general counsel, not a Greenberg ally, said that after Greenberg left, "no one was in charge." 145 The type and scale of practices at FP- and at the insurance subsidiaries- were novel adventures for A IG inconsistent with its cautious risk management. AIG's outside auditors discovered the gathering crisis in February 2008 and wrote to its chairman a scathing critique of top management and the governance and control environment they had created. ${ }^{146}$ The governance prescriptions clearly had a causal role in A IG's near-destruction. ${ }^{147}$

The case for a causal connection is supported, moreover, by the evidence that the reforms implemented at AIG reflected an unfortunate tendency among corporate governance experts to celebrate "best practices." That can readily lead to believing that certain devices are so appealing that they are suitable for every company without regard to particular governance realities. M any of those devices-such as making outside directors dominant on the board, separating the chairman and CEO roles, abolishing the executive committee, redesigning control oversight by creating new offices and committees-were put into place at AIG after the Spitzer-led prosecution, ordained by one considered to be a leading expert on the subject, A rthur L evitt.

$B$ ut these and other changes-including offering employment contracts with short-term bonuses and imposing age limits for directors-were implemented at AIG without giving consideration to its existing corporate governance attributes, including its entrepreneurial culture, employee-centric philosophy, employee-ownership and long-term incentive program, absence of employment contracts, strict internal control regimens, and reliance on experienced and engaged directors.

When evaluating how to proceed against corporate targets, prosecutors, in formal guidelines and practice, tend to emphasize compliance programs and cooperation. The A IG case study indicates that such an isolated focus can be perilous. Prosecutors must understand a corporation's broader overall corporate governance profile and work within it rather than ignore it (or try to revolutionize it). The AIG case study suggests the value of prosecutors taking an integrated approach to corporate governance by considering it from the outset to the end of a case, including in settlement under a DPA. The next Part pursues this suggestion more comprehensively.

\section{AN INTEGRATED APPROACH}

Given the degree of controversy surrounding DPAs, it is tempting to delineate a precise conceptual model of their legitimacy and prescribe exactly which terms are valid and which should be seen as off-limits. This Part considers alternatives, ultimately offering not so much a precise formula as calling for particular explanations of chosen terms based on an initial

\footnotetext{
${ }^{144}$ E.g., Oversight Report: The A IG Rescue, Its I mpact on M arkets and the Government's Exit Strategy (Elizabeth W arren, chair, J une 2010).

${ }^{145}$ Id. (quoting A nastasia K elly).

146 See supra note 141; GReEnBerg \& CUnNIngham, The AIG StORY, supra note 104 (reprinting the notes). Additional evidence, and another culprit, appears in the failure to detect any problems by an outside monitor installed at the company in another DPA on an earlier matter. See infra text accompanying notes 263-267.

${ }^{147}$ A nother hypothesis attributes the problems at AIG in 2008 not to anything that occurred after Greenberg left in early 2005 but to the complexity (often called "byzantine") of the company's structure or practices that existed in 2005 and before. In my research, see supra note 104, I did not find evidence to support that conjecture.
} 
investigation. The articulations would then form a body of knowledge providing considerable systemic advantages for the public and prosecutors alike. Section A explores DPA s in conceptual and analytical terms to define their proper scope, best seen neither as contract nor regulation but exercises of prosecutorial discretion. It concludes that such discretion warrants asking prosecutors to articulate the rationales of governance terms they proffer based on ex ante investigation. Section B explains the benefits of this approach compared to alternatives and Section $\mathrm{C}$ considers costs and various objections.

\section{A. Conceptualization: Contract, Regulation, Discretion}

The following discussion first probes the defining attributes of DPAs and then draws implications about their proper scope. Alternative conceptions view DPAs as pure contract (implicitly the status quo view), pure regulation (a stance directly at odds with the status quo) or as a device derived from prosecutorial discretion (the conception that emerges from the following analysis as most faithful to reality). To summarize: (a) under the contractual conception, no terms are off limits and bargains are policed solely by contract doctrines; (b) under the regulatory conception, the proper terms of DPAs would be exceedingly narrow, given the superiority of ex ante legislation or administrative rulemaking, putting governance terms offlimits; and (c) under the discretionary conception, the most apt, the range of proper terms is open-ended, and certainly includes governance terms, but warrants prudential limitation given broad prosecutorial power and limited judicial review.

\section{Pure Contract? The Implicit Status Quo Conception.}

Practice. The current practice concerning DPAs implicitly assumes that they are pure contracts to be governed primarily by contract law. No business organization is obliged to enter into one. Companies differ in their response to prosecutorial overtures, due to variation among governance participants such as directors, chief executives, general counsel and outside counsel. Every case differs due to variables such as the scope of alleged wrongdoing, the relative difficulty of proof, the costs of defending a case and the risk of losing customers or facing other constituent defections. Terms are negotiated and defense counsel in particular cases, as well as the organized defense bar, push back on given terms. As a result, not all DPAs or all terms in them should be seen as impositions akin to regulation.

Indeed, it seems that details venturing beyond fines and compliance into the deeper realms of corporate governance are more likely subject to greater negotiation. In any event, both sides to DPAs find the deals advantageous, each getting and giving something. At minimum, both sides avoid the costs and risks of a trial. In some cases, companies may find some governance changes appealing independent of the prosecutor's presence. Or prosecutors might propose simply adhering to requirements to which a company is committed, such as to maintain as many outside directors as applicable stock exchange rules require. ${ }^{148}$ Prosecutors may value

\footnotetext{
${ }^{148}$ DPA between DOJ and Friedman's, Inc. (2005).
} 
the bragging rights more highly as a way to boost a DPA's deterrence power. ${ }^{149}$ In such cases, including governance terms in a DPA is an inexpensive way to achieve closure.

Theory and Doctrine. Were DPA s purely contractual, contract theory would be relevant to the framework for assessing DPAs, and they would presumably pass muster given the foregoing observations about their features. They would be governed by the general law of contracts, with policing according to such doctrines as duress, illegal bargain and unconscionability. ${ }^{150}$ That is generally how plea agreements are handled. Courts declare that plea agreements are simply another form of contract, ${ }^{151}$ while appreciating special features emanating from constitutional protections ${ }^{152}$ and recognizing that plea agreements are formed only upon judicial approval in the settlement of a pending criminal action. ${ }^{153}$

In DPAs, the validity of certain terms-such as waivers of attorney-client privilege and restrictions on reimbursing legal fees- is suspect. In fact, since a federal court ruled that such terms were out of bounds in a DPA, the DOJ has eschewed them. ${ }^{154}$ This sequence of events is evidence that the contractual conception- and the status quo based on it- has some purchase. Private parties can obtain judicial review and declarations of lack of enforceability, on the grounds that some terms constitute illegal bargains. Certainly, it indicates the prospect and pressure of judicial review and a constraint on the exertion of excessive prosecutorial bargaining power.

Limits. Y et there are aspects of the DPA process that call the contractual conception into question. The balance of power in DPA negotiations may heavily favor prosecutors. First, companies know that an indictment could mean destruction, as in the case of A rthur A nderson. Second, in many cases, such as with AIG, DPA s are finalized after a firm's prior leadership has been removed and the deal is signed by successors happy to cast blame on predecessors.

Furthermore, were contract law to govern DPAs, some unusual provisions would likely produce results that would surprise participants. For example, absent express language disclaiming the creation of third party rights, it is possible that shareholders, competitors, customers and other members of the public may have enforcement rights on corporate breach. That would be so if a court concluded that the government intended to give such persons the benefit of the corporation's promises, ${ }^{155}$ which is plausible considering that prosecutors are charged with representing the interests of the public at large, including all such constituents. ${ }^{156}$ If

\footnotetext{
${ }^{149}$ Government's proper interests exclude any conclusions of lack of guilt, which would require dropping the case, but include factors such as sufficiency of the evidence and likelihood of success at trial. See authorities cited supra note 68 (series of DOJ memos concerning charges against corporations and other business organizations).

${ }^{150}$ See Candace Zierdt \& Ellen S. Podgor, Corporate D eferred Prosecution Agreements through the Looking Glass of Contract Policing, 96 K Y. L.J . 1 (2007).

${ }^{151}$ E.g., Brooks V. United States, 708 F.2d 1280, 1281 (7 $7^{\text {th }}$ Cir. 1983); see also Frank H. Easterbrook, Plea Bargaining as Compromise, 101 Y ALE L.J. 1969, 1974 (1992)

${ }^{152}$ See M abry v. J ohnson, 467 U.S. 504, 507-09 (1984).

${ }^{153}$ See, e.g., FED. R. CRIM. P. 11(e)(3)-(4).

154 U nited States v. Stein, 541 F.3d $130\left(2^{\text {nd }}\right.$ Cir. 2008).

${ }^{155}$ See Restatement (Second) of Contracts $\S 302(1)(b)$.

${ }^{156} \mathrm{Cf}$. Charles A. Sullivan, Enforcement of Government Antitrust Decrees by Private Parties: Third Party Beneficiary Rights and Intervenor Status, 123 U. PA. L. REV. 822 (1975); Larry K ramer, Consent Decrees and the Rights of Third Parties, 87 M ICH. L. REV. 321 (1988). Third parties have participation rights in plea agreements under restitution and victims' rights statutes, such as the Crime Victims' Rights Act of 2004, 18 U.S.C. § 3771. See Stephanos Bibas, Transparency and Participation in Criminal Procedure, 81 NY U L. REV. 911 (2006).
} 
this were the case, it would represent an extraordinary alteration of corporate governance powers. ${ }^{157}$

As another example, the power to declare corporate breach of a DPA is often reposed in the government's discretion and the government's remedy on breach is penal-an immediate suspension of the deferral and proceeding with a case, likely yielding indictment and conviction. Such a deliberately, and inherently, penal remedy may pose tensions with the compensation principle of contract remedies, casting doubt on the validity of such a DPA under traditional contract law principles. ${ }^{158}$ Accordingly, it may be difficult both to insist that DPAs are purely contractual and assume that they are enforceable as written.

$Y$ et, as a further mark of the limits of the pure contractual conception, when corporations allege breach of DPA s by prosecutors, courts do not automatically invoke contract principles to evaluate either the claim of breach or remedy. They rather defer to prosecutorial discretion over such basic matters as whether the government has surrendered contractual rights to pursue an indictment or not. ${ }^{159} \mathrm{But}$ the status quo is most objectionable if DPAs are conceived to be pure regulation, rather than pure contract.

\section{Pure Regulation? The M irror-Image Critique.}

DPAs are more akin to regulation than contract when one appreciates the massive imbalance of bargaining power prosecutors can command over targets. ${ }^{160}$ Prosecutors have extraordinary state powers in the DPA setting, far different in magnitude and type than the concept of relative bargaining power contemplated in the real $m$ of contract practice. It is not as if the corporation is negotiating a loan agreement or long-term lease with the chosen one among many lenders or landlords in the market. It faces a government agent wielding monopoly power. ${ }^{161}$ The DPA is a sword over the corporation's head. ${ }^{162}$ DPAs have other regulatory

\footnotetext{
${ }^{157}$ Cf. M iriam Hechler B aer, Organizational Liability and the Tension between Corporate and Criminal Law, 19 J . L. \& POL'Y 1 (2011).

158 Probation differs. Probation contracts, formed between a convicted offender and a judge, are made after a defendant is sentenced and consist of the suspension of that sentence so long as stated objective conditions are met. Failure to meet those conditions lifts the suspension and results in incarceration. See J oan Petersilla, Probation in the U nited States, 22 CRIME \& JUST. 149, 164 (1997). In DPAs, there has been no sentence (or conviction) that is merely being conditionally suspended. What's being conditionally deferred is the indictment or prosecution and the combination of features that give rise to breach - often by unilateral government declaration-and remedy-a stipulation to given facts al most guaranteeing conviction- makes the result more consciously penal, even draconian, compared to probation contracts.

${ }^{159}$ Stolt-Nielsen, S.A. v. U nited States, 442 F.3d 177 (3d Cir. 2006), cert. denied 549 U.S. 1015 (2006); infra text accompanying notes 168-172.

${ }^{160}$ Expressed in terms of economic theory, contracts usually manifest an efficient bargain. Bargains between prosecutors and corporations memorialized in DPAs might be efficient also, to the extent that they reflect the features referenced in the preceding discussion of DPAs as pure contracts. Y et there may be circumstances in which contracts, including DPAs, are inefficient due to some form of "market failure." Examples are massive imbalance in bargaining power or DPA s concluded by successor corporate officials eager to blame their predecessors.

${ }^{161}$ This is monopsony power if the government is seen as a buyer of admissions rather than the seller of deferral. See J effrey Standen, Plea Bargaining in the Shadow of the Guidelines, 81 CAL. L. REV. 1471 (1993).

${ }^{162}$ See BRENT FISSE \& J OHN BRSITHWAITE, CORPORATIONS, CRIME AND A CCOUNTABILITY 15 (1993).
} 
qualities as well, including that violations expose the private party to public criminal law enforcement sanctions. ${ }^{163}$

Ad Hoc Inferiority. Conceived as pure regulation, prosecutorial interventions are ad hoc solutions to systemic problems better addressed by legislation or administrative rulemaking ex ante rather than prosecutors ex post. ${ }^{164}$ Optimal deterrence is best achieved by inducing corporations to maintain effective internal policing by adopting ex ante duties-generally applicable to firms rather than targeted to a particular one. Hence general federal laws (such as the Organizational Sentencing Guidelines) encourage all companies to maintain effective compliance programs and specific substantive regulations (such as addressing drug labeling or money laundering) establish industry-wide or generally applicable duties addressed to all companies. This value is particularly high when accompanied by articulation of rationales, whether through legislative history such as committee reports or administrative agency statements such as those publicized during the course of seeking notice and comment on proposed regulations. ${ }^{165}$

Within such a regime, as a theoretical matter, there is little or nothing left for DPA s to do. At best, DPAs could contain terms tailored to matters over which such duty-based criminal liability and general regulation are somehow ineffective. This universe of problems is probably limited to terms that are designed to reduce the costs of managerial deviation from optimal policing. That is, they address problems particular firms have, such as when managers face private incentives to commit crimes. In the vocabulary of corporate law scholarship, these are collectively called the agency costs of policing. As a procedural matter, laws and regulations made ex ante command legitimacy by concordance with norms of publication, open government and access to law. ${ }^{166}$

Narrow Scope. Under this conception of DPAs as pure regulation, it may be defensible for a prosecutor, on an ex post and firm-specific basis, to call for a particular company not only to maintain an effective compliance program against money laundering say (as all financial institutions must) but also to engage a special officer whose job is to assure that effectiveness. A DPA could likewise properly call for an independent monitor to oversee that person or antimoney laundering processes. A $n$ additional rule could require that such personnel be authorized to report directly to the corporation's board chairman or outside directors. ${ }^{167}$

Such arrangements would be defensible attempts to reduce agency costs associated with internal policing-i.e., managerial incentives to avoid optimal compliance for personal gain. But, under the regulatory conception, prosecutors should be discouraged from proffering corporate governance terms that go beyond compliance. Delimiting DPA terms to those addressing agency costs of policing has some theoretical appeal and offers a way to curtail prosecutorial excesses.

\footnotetext{
${ }^{163}$ Garrett, supra note 2; Rachel Barkow, Organizational Guidelines for the Prosecutor's Office, 31 CARDozo L. REv. 2089 (2011); Rachel Barkow, Institutional Design and the Policing of Prosecutors: Lessons from Administrative Law, 61 STAN. L. REV. 869 (2009).

${ }^{164}$ See A rlen \& K ahan, supra note 89 (developing this approach).

165 See Richard J. PierCe, JR., et Al., A dm InISTRA tive LAW ANd Process 420-23, 476-85 (3d ed. 1999).

166 See Lawrence A. Cunningham, Private Standards in Public Law: Copyright, Lawmaking and the Case of Accounting, $104 \mathrm{MICH}$. L. REV. 291, 331 (2005) ("a powerful norm pulsing through the administrative lawmaking function requires publication of regulatory promulgations in the spirit of open government and public access to law").

${ }^{167}$ The 2010 amendments to the OSG s give targets credit for such a provision.
} 
Y et given contractual features of DPAs, this conception of DPAs as pure regulation is not entirely faithful to reality.

\section{Prosecutorial Discretion: M ost Faithful to Reality.}

There is a fundamental problem with conceiving of DPAs as pure contracts or pure regulation or even a hybrid. True, such conceptions may help evaluate the appeal of DPA s or assess their proper scope, but a more immediate question appears: the legality of a DPA, which is to say its enforceability in court. From the judicial perspective, the conceptualization of DPA s as contracts or regulation may be trivial compared to conceptualization of them as products of prosecutorial discretion.

Limited J udicial Review. Prosecutorial practice and venerated traditions of prosecutorial discretion put DPAs substantially beyond the scope of meaningful judicial review. An original rationale for DPAs is to enable handling probable criminal wrongdoing with limited formal public procedures such as an indictment. True, upon declaration of breach by the government, the corporation may be able to obtain judicial review. But given the typical terms-government having power to declare breach and the remedy being proceeding immediately to prosecution on admitted facts- the corporation will face pressure unique to DPAs.

Consider al so the opposite case, of a corporation's declaration of prosecutorial breach. ${ }^{168}$ A corporation may object that the prosecution sought to indict it despite a DPA and the corporation's cooperation and compliance, declaring breach and seeking to enjoin the indictment. But federal courts do not necessarily classify such cases as involving contracts or regulation, citing prosecutorial discretion. ${ }^{169}$

As the Supreme Court has explained, prosecutorial discretion is entailed by constitutional separation of powers, in which the "executive branch has exclusive authority and absolute discretion to decide whether to prosecute a case." ${ }^{170}$ A longstanding feature of the separation of powers based conception of prosecutorial discretion is that the judicial branch generally lacks jurisdiction to enjoin a criminal prosecution. ${ }^{171} \mathrm{Narrow}$ exceptions to this jurisdictional limit concern enforcing government-defendant agreements, but even such agreements are construed strictly in the light of the constitutional separation of powers. ${ }^{172}$

$M$ any object to prosecutorial discretion, of course. Critics claim overreaching due to biased discrimination, political aspirations, excessive zeal and, for DPAs, intrusion into the domain of corporate governance. Solutions include constraining prosecutorial discretion by greater delineation of substantive criminal law or legislative or judicial review of prosecutorial judgments- or, for DPAs, ruling governance off limits by statute or perhaps strengthening the role of grand juries in the process. ${ }^{173}$ Judicial review may nominally be required of DPAs upon

\footnotetext{
${ }^{168}$ Stolt-Nielsen, S.A. v. U nited States, 442 F.3d 177 (3d Cir. 2006), cert. denied 549 U.S. 1015 (2006).

${ }^{169}$ Technically, the agreement, with the A ntitrust Division of the DOJ, was a leniency agreement, but the differences between such traditional tools of that Division and the more general class of DPA s is immaterial in this context.

${ }^{170}$ U nited States v. Nixon, 418 U.S. 683, 693 (1974).

${ }^{171}$ See U nited States v. Cox, 342 F.2d 167, 171 (5th Cir.1965) (en banc).

${ }^{172}$ For criticism of this stances, see Sarah B aumgartel, Nonprosecution Agreements as Contracts: Stolt-Nielsen and the Q uestion of Remedy for a Prosecutor's Breach, 2008 W IS. L REV. 26 (2008).

173 See Roger A. Fairfax, Jr., Grand J ury Innovation: Toward a Functional Makeover of the Ancient Bulwark of Liberty, 19 W M. \& MARY BILL OF RIGHTS J. 339, 359-360 (2010).
} 
execution for technical reasons, ${ }^{174}$ but no judge has ever rejected a DPA ${ }^{175}$ and many do not even hold a hearing when asked to review them. ${ }^{176} \mathrm{~A}$ jurisdiction may require prosecutors who ultimately decide to drop a criminal case to file a written statement of reasons with a court for its approval. ${ }^{177}$

Prosecutorial discretion has staunch defenders as well and even its toughest critics acknowledge the necessity of some discretion. ${ }^{178}$ L egislators and judges seem to appreciate that too, as they have not interfered significantly with prosecutorial discretion. For DPAs, such interference would be of uncertain value. It would put judges, individuals with limited investigative resources and institutional competence, in the difficult position of second-guessing prosecutors having conducted an investigation and engaged in negotiations with targets. Drawbacks also include adding a layer of costs. A nother important indirect cost: sharing responsibility with the judicial branch does not stimulate prosecutors to prepare governance profiles ex post, an important objective of the integrated approach, the seminal lesson of Andersen and a vital lesson of AIG.

Prosecutorial discretion is a bulwark against excessive disclosure of matters better kept confidential. Obvious examples concern protecting victims or witnesses and maintaining the confidentiality of internal investigation and deliberation. Less obvious is how opacity can usefully obscure law enforcement resource constraints that can undermine deterrence. An excessively transparent process would reveal resource constraints that may have adverse effects on the public's confidence in law enforcement or in its deterrent value. Relative opacity may offer other benefits such as promoting public confidence in the fairness and efficiency of criminal law enforcement. ${ }^{179}$ When such concerns are not at stake, or are outweighed by other factors, prosecutors make exceptions, providing written explanations for decision in given settings, such as declining to prosecute or giving reasons in individual cases. ${ }^{180}$

Restraint. The solution becomes prosecutorial restraint, which evidence demonstrates can be highly effective. ${ }^{181}$ For example, evidence drawn from recently-publicized records in several big-city prosecutors' offices, such as New Orleans and M ilwaukee, includes written statements of reasons for decisions, including decisions not to prosecute. ${ }^{182}$ The reasons given showed prosecutors making reliable judgments in accordance with law. They lacked the completeness of

\footnotetext{
${ }^{174}$ E.g., 18 U.S.C. $§ 3161(h)(2)$ (allowing for deferral period to be excluded from counting time elapsed before trial if deferral agreement is judicially approved).

${ }^{175}$ GARRETT, TOO BIG TO J AIL, supra note 11, ch. 3 at $18 \& 37$.

${ }^{176}$ U.S. GOV'T A CCOUNTABILITY OFFICE, GA O-10-110, supra note 83, at 25 (2009) (9 out of 12 judges interviewed did not conduct hearing before approving DPAS).

177 E.g., Nebraska Rev. STAT. § 29-1606; cf. SEC v. Citigroup Global Markets, Inc., 673 F.3d 158 (2d Cir. 2012) (criticizing district court judge J ed Rakoff's assertion of power to upset settlement between regulatory agency and corporation).

${ }^{178}$ See Stephanos Bibas, The Need for Prosecutorial Discretion, 19 TEM P. PoL. \& CIV. RTS. L. ReV. 369 (2010).

${ }^{179}$ See Tom Baker, A Ion Harel \& Tamar Kugler, The Virtues of Uncertainty in Law: An Experimental Approach, 89 IOWA L. REV. 443 (2004).

180 See Richard S. Frase, The Decision to File Federal Criminal Charges: A Quantitative Study of Prosecutorial Discretion, 47 U. CHI. L. REV. 246, 292-95 (1980); J ohn Eligon, Strauss-Kahn Drama Ends with Short Final Scene, N.Y. TIM ES (A ugust 23, 2011) (referencing 25-page memo prosecutor Cyrus $V$ ance released articulating reasons for declining to proceed with prosecution of French dignitary alleged to have committed sexual assault in the U.S.). The narrow exception for DPAs is warranted because this setting does not ordinarily implicate such broad-gauged problems and, when they might, confidential treatment can be provided accordingly.

${ }^{181}$ See M arc L. M iller \& Ronald F. W right, The Black B ox, 94 IowA L. REV. 125 (2008).

${ }^{182}$ Id.
} 
judicial opinions, but the brief statement of rationales demonstrated a pattern of valid reasons at work, rather than abuses of discretion warranting judicial review or legislative constraint.

In the case of DPAs, a similar exercise, with public statements of the rationales, would be useful. A fter all, prosecutors occupy a special position as ambassadors for justice, quasi-judicial officers, and thus have some duty to look out for the interests of the target corporation and its constituencies. ${ }^{183}$ Important strands of the principle of prosecutorial neutrality direct prosecutors to act as objective public servants, whose clients are the public, and they do not represent partisan interests. ${ }^{184}$ J ust as judicial supervision of unconscionable bargains invokes paternalistic impulses, prosecutors negotiating DPAs must protect the interests of their counterparties and must not act arbitrarily. ${ }^{185}$

The integrated approach to DPAs is drawn narrowly to minimize infringement on prosecutorial discretion. The articulation practice addresses only governance terms in DPAs, not reasons for deferral, fines imposed or admissions obtained. DPAs may be novel and controversial but those should not necessarily be the tests warranting a call for public articulation. It is the uncharted territory, and the damage that can be done to large organizations and related innocents, that prompts this call. ${ }^{186}$

No broader call for articulation is warranted. There are many contexts in which scholars have considered asking for public statements of prosecutorial decision-making. One example concerns prosecutorial decisions not to file charges-declinations akin to DPAs that some believe can amount to prosecutorial nullification. ${ }^{187} \mathrm{~A}$ public statement of reasons would address that concern but also prove burdensome, costly and ultimately unwieldy.

In short, the best way to conceptualize the DPA is not so much as a species of contract or regulation but as a product of prosecutorial discretion and to think about its proper scope and limits as such. So conceived, prudential prosecutorial restraint warrants the integrated approach of asking prosecutors to prepare a corporate governance profile ex ante as part of their investigation of corporate targets and then publicly articulating the rationales for corporate governance terms in DPAs when settling cases. Assuming such steps, prosecutors should feel free to proffer such terms, which would produce considerable net benefits, both systemic and parochial.

\section{B. Comparative Benefits of the Integrated A pproach}

This Section probes the comparative benefits of the three conceptions analyzed in the previous one, showing the net superiority of the integrated approach-that is, the conception of DPA s as products of prosecutorial discretion and the call for prosecutors to prepare a governance profile ex ante and articulate rationales for governance terms ex post. Discussion first identifies advantages of the integrated approach over both the pure contract and the pure regulation conception; advantages it offers over the pure regulation conception alone; and advantages it

\footnotetext{
${ }^{183}$ See Stanley Z. Fisher, In Search of the Virtuous Prosecutor: A Conceptual Framework, 15 A M . J. CRIM .. L. 197, 215-17 (1988).

${ }^{184}$ See Bruce A. Green \& Fred C. Zacharias, Prosecutorial Neutrality, 2004 W IS. L. REV. 837, 866 (2004).

$185 \mathrm{Id}$. at 870 . Far from returning the analysis to contract law, these observations underscore why conceiving of DPA s as products of prosecutorial discretion is more faithful to reality.

${ }^{186}$ A nother reason for this narrow focus is that these are the terms most likely to be improved by an articulation practice, as discussed infra text accompanying notes 189-195.

${ }^{187}$ Roger A. Fairfax, J r., Prosecutorial Nullification, 52 B.C. L. Rev. 1243 (2011).
} 
offers over the pure contract conception alone. (The ensuing Section considers costs and other potential objections.)

\section{Integrated A pproach v. Pure Contract and Pure Regulation Conception.}

Improved Decision Making. A practical problem with the pure regulation conception's barring prosecutors from proffering governance reforms ex post is how it discourages prosecutors from considering governance ex ante. The pure contract conception creates the same disincentive for a different reason, signaling to prosecutors that there is no need to give governance terms any more thought than is given to any term in any ordinary contract. A primary advantage of the integrated approach is that it would lead prosecutors to invest in understanding a target's governance profile, which would improve the quality of their analysis ex ante and ex post.

All the varied aspects of corporate governance, referenced above in Part I, would be potentially probative. Prosecutors would include the creation of a basic profile as part of the initial investigative phase of a case, to be updated throughout, and providing a basis on which to negotiate DPAs. Such knowledge likely would imply different signals to prosecutors about how to proceed, as with an indictment or to settle. In some cases, that would lead to eschewing the DPA in favor of proceeding with an indictment and perhaps trial and conviction. In cases where settlement is indicated, the ex ante profile would inform prosecutorial judgment about appropriate changes.

Tailoring. A related advantage of the integrated approach is the opportunity to fix specific problems within a company. A fter all, governance terms operate differently at different companies, and the formal uniformity of typical regulatory conceptions obscures that. ${ }^{188}$ DPAs can supply custom tailored terms that ex ante legislation and administrative rulemaking cannot.

The practice of articulation, moreover, would improve the fit of tailored terms to given firms. Providing written reasons for decisions tends to improve the quality of decision making, in most settings. ${ }^{189}$ This is one of several values underlying the widespread practice in the U.S. of judicial opinion writing and in regulatory statements accompanying proposed rulemaking by administrative agencies. ${ }^{190}$ The legal community agrees that such writing improves reasoning, especially concerning legal decision-making. ${ }^{191}$ Prosecutors do not routinely give reasons for their decisions, but current research indicates that prosecutors believe that articulation of reasons benefits their decision making too. ${ }^{192}$

Evidence from psychological research largely affirms such beliefs. ${ }^{193} \mathrm{~W}$ ritten rationales sharpen the reasoning, which improves decision making. It appears to be most effective for decisions that involve factors that are relatively finite, causal, logical, precise and technical ${ }^{194}$ the characteristics of corporate governance terms. Not all decisions require written reasons, of

\footnotetext{
${ }^{188}$ See supra text accompanying notes 49-51.

${ }^{189}$ See Chad Oldfather, Writing, Cognition and the Nature of the J udicial Function, 96 GEO. L. J. 1283 (2008).

190 See Jodi L. Short, The Political Turn in American Administrative Law: Power, Rationality, and Reasons, 61 DUKE L.J . 1811 (2012).

${ }^{191}$ See Frederick Schauer, Giving Reasons, 47 StA N. L. Rev. 633 (1995).

192 Ronald W right, e-mail to Lawrence A. Cunningham (Oct. 13, 2012) (referencing interviews with some 200 prosecutors in recent two-year period on qualitative project that reflects such beliefs).

${ }^{193}$ Oldfather, supra note 189 , at 1321-22.

${ }^{194}$ Id.
} 
course, and there is no imperative to explain the obvious or to reach for reasons when a decision is reasonably made on the basis of hunch or intuition - where research suggests writing exercises can actually be counterproductive. ${ }^{195}$ For DPAs, the decision to defer and the fines set may be respected as products of hunch and intuition whereas the choice of particular substantive governance terms calls for reason. The articulation practice should thus improve the tailoring of fit between terms and targets.

Generality. A third factor affecting the relative appeal of conceiving of DPAs as contractual, regulatory or discretionary concerns how each conception deals with the variety of prosecutors' offices in the United States, which vary greatly in many ways. ${ }^{196}$ For instance, institutional differences distinguish federal district offices from state and local offices, with many state attorneys general having more autonomy than federal counterparts and many local prosecutors being elected rather than appointed. Caseloads differ, with the Sothern District of New Y ork handling more corporate matters than the Southern District of Texas, for example. The relative efficacy of ex ante regulation or ex post judicial or legislative review may diverge across settings.

All such factors are potentially relevant to defending a conception of DPAs as either contracts or regulation but, more important, would be relevant to assessing the validity, as a matter of contract or regulation, of given DPA terms. Relative bargaining power would influence whether a DPA is best conceived as contract but also whether it is the reasonable product of volition rather than an unconscionable result of duress. The efficacy of ex ante regulation- say for local law regulating taxi fleets or liquor sales- would be relevant to evaluating the validity of a DPA term requiring a corporation to create a chief public safety officer. The relevance of such factors dissolves when DPAs are appreciated as species of prosecutorial discretion as each prosecutors' office exercises discretion in accordance with its unique features and completes the requested investigation and explanation accordingly. ${ }^{197}$

\section{Integrated A pproach v. Pure Regulation Conception.}

Line Drawing. Compared to the pure regulation conception, an advantage of the integrated approach is overcoming line drawing problems. Under the conception of DPAs as pure regulation, legislators or prosecutors would have to distinguish between compliance terms, deemed proper, and governance terms, ruled out-of-bounds. Compliance is a sub-set of corporate governance but particular devices may evade ready classification. Consider a provision appointing a chief compliance officer who reports directly to the board, a term composed of both compliance and governance attributes. M ore broadly, consider the example of disclosure, which DPAs invariably require corporations to make: disclosure is an important topic of corporate

\footnotetext{
195 See Charles M. Y ablon, J ustifying the Judge's Hunch: An Essay on Discretion, 41 HASTINGS L.J. 231 (1990); Chris Guthrie et al., Blinking on the Bench: H ow J udges D ecide Cases, 93 CORNELL L. Rev. 1 (2007).

${ }^{196}$ E.g., Michael L. Benson \& Francis T Cullen, Combating Corporate Crime: Local Prosecutors at W ORK 45-49 (1998); Stephanos Bibos, Regulating Local Variations in Federal Sentencing, 58 STAN. L. ReV. 137 (2005); supra note 2.

${ }^{197}$ Other differences that dissolve include the extent to which prosecutors coordinate with regulatory authorities on any given case. While relevant to evaluations of DPA s as contracts or regulation, this simply becomes an element of the exercise of prosecutorial discretion when DPAs are conceived as such. Cf. supra note 75.
} 
governance, but may be an equally important topic of corporate compliance. Under the integrated approach, no line drawing is required. ${ }^{198}$

Scope of Purposes. A nother advantage of the integrated approach compared to the pure regulation conception concerns the purposes of DPAs. The conception of DPAs as pure regulation entails not only putting governance terms off-limits but testing the validity of compliance terms based on their deterrence value, by hypothesizing employee calculations concerning whether to comply with law or not. ${ }^{199}$ But this approach would ignore the recognized school of thought holding that people comply with law because of norms of obedience that arise from features of a system that give it legitimacy. ${ }^{200} \mathrm{M}$ any governance mechanisms fit the bill, not merely technical compliance devices. ${ }^{201}$ Prosecutors speak of achieving rehabilitation aims, changing corporate culture, from one oriented toward corruption to one embracing compliance, and governance devices may serve such goals. ${ }^{202}$

Better Regulation. Under the pure-regulation conception, ex ante legislation and administrative rulemaking are preferred to ex post tailoring. $Y$ et one widely recognized problem with general regulation that occurs following financial crises is the risk of over-reaction amid widespread psychological and political pressure. ${ }^{203}$ True, after scandal, populist backlash against those perceived to have been at the heart of problems can increase risk of exuberant prosecutorial enforcement. ${ }^{204}$ But such pressures appear less problematic in given DPAs with a particular company. One reason may be the direct bargaining that occurs between prosecutors and corporations in the DPA setting compared to the bustle of national politics where lobbyists battle each other. In any event, the prescribed articulation practice would curb excesses.

Innovative, tailored terms that are explained when adopted could also prove to have value that could be fruitfully adapted to other firms or even to provide the basis for broadly-applicable law or rule. Experimentation accompanied by explanation would likely improve the development of tools that promote deterrence and compliance.

\section{Integrated A pproach v. Status Quo.}

The chief advantages of the integrated approach compared to the status quo concern the prospect of formalizing, systematizing and cataloguing what has emerged as a spontaneous and

\footnotetext{
${ }^{198}$ O ne approach to such line-drawing challenges would classify all hybrid devices as compliance and condone their inclusion in DPAs. Indeed, the class of compliance devices could simply be enlarged to admit any device that has more than a remote potential contribution to compliance. Defined thus broadly, many terms that might routinely be thought of as governance devices would be ruled in. Examples of terms that could be fairly deemed compliance rather than governance include the removal and replacement of officers, the expansion of a corporate board and populating it with new outside directors, designation of new committees addressing compliance as well as risk, legal affairs, or even auditing, environmental matters and so on. There is nothing inherent about many terms that warrant objecting to their inclusion per se. Each term should be taken on its own and evaluated for its role in the given corporation. Judgments made contextually are likely superior to rules stated abstractly.

199 See Gary B ecker, Crime and P unishment: An Economic Approach, 76 J. POL. ECON.169 (1968).

200 See Tom R. Tyler, Why People Obey the Law (2006).

${ }^{201}$ See Cynthia A. Williams, Corporate Compliance with the Law in the Era of Efficiency, 76 N.C. L. REv. 1265 (1998); M iriam Hechler Baer, Corporate Policing and Corporate Governance: What Can We Learn from HewlettPackard's Pretexting Scandal, 77 U. CIN. L. ReV. 523 (2008).

${ }^{202}$ See supra note 11 and accompanying text.

${ }^{203}$ See supra note 50 and accompanying text.

${ }^{204}$ See B aer, Choosing Punishment, supra note 4.
} 
opaque set of practices. DPA practice also appears to be haphazard, although there is evidence that senior lawyers at the D0 J, at least, are attempting to systematize it. ${ }^{205}$ That effort supports the view that the status quo could use improvement. A dvantages arise from the proposed practice of public articulation of the rationales for governance terms included in DPA s. A side from how they may improve the quality of decision making as noted earlier, such written rationales are valuable as precedent and as a source of legitimacy.

Precedent. Precedent is valuable as a resource to guide resolution of future cases in accordance with kindred treatments of others in previous cases. ${ }^{206}$ The articulation practice would provide a record of the thought process prosecutors and counterparties followed when coming to agreement on governance terms. Such a system would contribute a base of knowledge on which prosecutors and corporations could draw in future cases, generating fairness gains akin to those of stare decisis and efficiency gains by reducing the costs of negotiation and settlement and increasing the quality of tailoring terms to particular settings.

Legitimacy. Legitimacy, a complex multifaceted concept, encompasses the notion of justifications for legal decisions. ${ }^{207} \mathrm{M}$ aking such justifications public increases the value of legal justification. ${ }^{208}$ Otherwise, participants and the public may be mystified, confused, and unable to evaluate the decision fairly. One rationale for published articulation as a source of legitimacy is the reasoned elaboration provided, demonstrating that a decision is based on more than fiat, office or position, but principle with a claim to independent respect. ${ }^{209}$

Derivative values include creating the capacity for outsiders to assess the reasoning and its fidelity to prevailing standards and related values such as stare decisis. True, few writings can provide a comprehensive and faithful account of all reasons, as few judicial opinions do, yet the exercise constrains discretion to concord with the criterion of legitimacy. ${ }^{210}$ Such ability adds the value of perceived legitimacy, as the public can more confidently accept the judgments of those who explain themselves under the valence of neutrality than those who act by fiat or demand to be trusted with power.

The value in the context of DPAs with business organizations seems even more likely to be pronounced. An authoritative statement of why governance changes are being made would benefit all corporate constituents-including directors, officers, employees, gatekeepers and shareholders. In corporate settings where internal communications are part of the governance apparatus, it may seem odd to employees that such results are not explained by authorities. The authoritative statement of rationales would communicate institutional resolve, often necessary to induce employees firm-wide to take governance and compliance measures seriously.

Critique. DPAs produced without explanation expose participants to criticism when the rationale for particular terms is unclear and open to competing interpretations. $M$ any governance terms often seem jarring to corporate lawyers and other observers that, if explained in context,

\footnotetext{
${ }^{205}$ See GARRETT, TOO BIG TO J AIL, supra note 11.

${ }^{206}$ See Frederick Schauer, Precedent, 39 Stan. L. Rev. 571 (1987); KarL N. LleWelly n, The Bramble Bush 75 (1996).

${ }^{207}$ See M icah Schwartzman, The P rinciple of J udicial Sincerity, 94 V A. L. REV. 987 (2008).

${ }^{208}$ Id. at 1055.

${ }^{209}$ See G. Edward W hite, The Evolution of Reasoned Elaboration: J urisprudential Criticism and Social Change, 59 V A. L. REV. 279 (1973); Lon L. Fuller, The F orms and Limits of Adjudication, 92 HARV. L. REV. 353 (1978).

${ }^{210}$ See Lawrence A. Cunningham, The Common Law as an Iterative Process: A Preliminary Inquiry, 81 N OTRE DAME L. REV. 747 (2006).
} 
might be better understood. ${ }^{211} \mathrm{No}$ doubt, they may seem jarring to employees and others within the organization with whom they directly deal. With articulations, critics would challenge the stated rationale of a term rather than the unadorned term as it appears on the face of a contract. Whatever the reaction, observers would have a firmer foundation to provide criticism- or praise- when reviewing DPAs.

Prosecutorial Error and Overreach. Current practice leaves no reliable record of reasoning, one of the important functions of offering public justifications. ${ }^{212}$ The AIG case study is a good example, where despite investigation, through interviews and primary sources, it is difficult to be certain exactly why certain steps were taken or even when or by whom. ${ }^{213} \mathrm{~A}$ record from participants would have been intrinsically valuable and checked the risk of prosecutorial error, a product of the improved decision-making that written reasons offer, and overreach, a product of their legitimation function. Had Spitzer been compelled to understand AIG's governance at the outset, and he and Levitt and others constrained to explain why their proffered terms made sense for AIG, the risk of oversight and inattention would have been diminished.

Such an effect would likewise check the risk of prosecutorial overreach. Prosecutors may be motivated to settle a case using a DPA for a wide variety of reasons. ${ }^{214}$ These can be arrayed along a continuum relating motive to the merits or relative legitimacy. A t one end would be the clearly legitimate avoidance of risks of adverse collateral consequences of organizational indictment and mitigating concerns over uncertainty of trial and achieving efficient case closure. Toward the other end are objectives such as bragging rights, which may or may not promote such valid goals as deterrence and, perhaps at the very end, advancing political objectives in running for higher office. Whatever the motivations, however, the integrated approach (investigation and articulation) should channel them toward the legitimate end of the continuum.

Prosecutorial Gains. A special appeal to the interests of prosecutors should not be ignored. Gains to prosecutors from the articulation practice arise from the overall program of building a body of valuable knowledge. These benefits are akin to those judges derive from the practice of opinion writing and regulators from drafting releases for public comment, which share many of the same objectives- precedent, stare decisis, efficiency, legitimacy, neutrality and transparency. Such exercises help to expand their authors' power, especially among branches of government. ${ }^{215}$ Likewise, leadership positions and reputations can be made by publishing outstanding accounts of decisions. ${ }^{216}$

Transparency. $M$ any of the foregoing advantages are particular examples of the broader feature of transparency that articulation practice would provide. Transparency is valuable for public acceptability. The public is more likely to accept the practice of legal settlements between government and corporate defendants when the related terms, including underlying reasons, are explained. Transparency carries downsides, a cost to those who would prefer to operate behind

${ }^{211}$ Cf. M elvin Aron Eisenberg, Participation, Responsiveness, and the Consultative Process: An Essay for Lon Fuller, 92 HARV. L. REV. 410, 412 (1978).

${ }^{212}$ See J ames B oyd W hite, What's An O pinion F or?, 62 U. CHI. L. REV. 1363 (1995).

${ }^{213}$ See supra note 104.

${ }^{214}$ See supra text accompanying note 85.

${ }^{215}$ See Thomas W. M errill, J udicial O pinions as Binding Law and as Explanations for J udgments, 15 CARDozo L. REV . 43, 44-45 (1993).

${ }^{216}$ See David K lein \& Darby Morrisroe, The Prestige and Influence of Individual Judges on the U.S. Courts of Appeals, 28 J. LEGAL STUD. 371 (1999). 
closed doors. Some prosecutors, and perhaps many defense lawyers, may prefer, at least in some cases, a more opaque process. There can be valid reasons for such a preference, including to protect the identity of witnesses or whistleblowers or to protect proprietary business matters. ${ }^{217}$ Prosecutorial discretion should be maintained for these purposes, while preserving the other benefits of transparency.

\section{Costs and Other Potential Objections}

Direct Costs. Few proposals for change are without costs and there are certainly costs associated with the integrated approach. They should be reasonably low, however, and offset by the substantial gains from error reduction ex ante and improved effectiveness and other benefits ex post. As a frame of reference, federal regulations call for the DOJ to conduct a cost-benefit analysis of any proposal that would likely have an annual impact on the economy of $\$ 100$ million or more. ${ }^{218}$ It does not seem likely that this proposal would entail such high incremental costs. ${ }^{219} \mathrm{~N}$ evertheless, a rough cost summary is worth sketching - and should then be compared to the benefits hypothesized in the previous Section.

The prescribed corporate investigation would require that an additional team of prosecutors or investigators be dispatched to conduct a governance profile ex ante, and this may require engaging the assistance of outside experts at some cost. ${ }^{220}$ Some of the associated fixed costs, however, already are incurred in current practice. The investigation involves interviewing executives or employees and sometimes third parties and reviewing documents. The specific search for information on corporate practices and structures and extraction of it, as well as related analysis, would add incremental costs. But preparing a useful profile of even a relatively large company should be possible with 100 to 300 hours of effort- that incurred to develop the A IG profile summarized in Part II took far less. Charged at a rate of up to $\$ 500$ per hour, that yields approximate costs of no more than $\$ 150,000$.

During the settlement process, the incremental costs of articulation are more modest. Under current practice, prosecutors do much of the required work concerning articulation. At the DPA drafting stage, prosecutors submit work for higher-level approval that would include memoranda explaining the basis for the agreement and recommendation. Such a practice assures that prosecutors operate within the agenda of their offices. It does entail additional work but, as the examples in the next Part of this A rticle will show, the envisioned articulation exercise is not

\footnotetext{
${ }^{217}$ See supra notes $179-180$ and accompanying text.

${ }^{218}$ See Executive Order 12866 § 3(f); Office of M anagement and Budget, Circular A -4.

${ }^{219}$ As an imperfect proxy, the average annual number of DOJ DPA s in the past decade is less than 40 . To have an impact of at least $\$ 100$ million would mean that incremental costs per case equal or exceed $\$ 2.5$ million. Chief incremental costs per investigation and DPA are up-front investigation efforts and ex post articulation practices. As explained below, the additional costs of investigation are unlikely to exceed $\$ 150,000$ and the additional costs of settlement unlikely to exceed $\$ 50,000$. True, the total costs would be greater by virtue of ex ante investigations that may not lead to DPAs but even that added cost is unlikely to result in costs exceeding $\$ 100$ million annually.

${ }^{220}$ This exercise would be part of the preliminary investigation and consist of assembling a corporate governance profile, akin to that business lawyers might provide ahead of a corporate acquisition, see JAMES C. FREUND, ANATOMY OF A M ERGER (1975), or underwriters might use to quote premiums for directors' and officers' insurance, see Sean J. Griffith, The M issing M onitor in Corporate Governance: The Directors' \& O fficers' Liability Insurer, 95 GEO. L. J 1795 (2007). M uch of the content for public companies would be publicly available; non-public details could be readily obtained by prosecutors exercising standard investigative powers, including the subpoena power.
} 
overwhelming. ${ }^{221}$ In an analogous context, private plaintiffs' lawyers settling derivative shareholder lawsuits based on governance reforms rather than money obtain independent legal opinions that the reforms confer substantial benefits-an exercise in which law professors are often engaged at a total cost rarely exceeding $\$ 50,000 .{ }^{222}$

When weighing costs and benefits, one objection may be that the frequency of governance terms proffered for DPA s is low compared to the number of investigations openedas many investigations close, proceed through prosecution, or are resolved using DPAs that do not include governance terms. If so, it might follow that costs of ex ante investigation would arguably be wasted, warranting prosecutors to defer developing requisite rationales until the DPA stage when it is known that governance terms are to be negotiated. However, the integrated approach to investigation and reform being proposed includes a prominent role for the investigation stage, independent of the governance terms in DPAs. The Andersen case makes clear the importance of considering governance features at the outset, without regard to whether the topic ever arises in a DPA. The AIG case reinforces that lesson, as prosecutors should have proceeded with greater caution amid the company's ongoing governance debate over executive succession.

A final point about the proposed integrated approach is that incremental costs should not be so great as to dissuade prosecutors from pursuing DPA s in cases where that is judged to be the best outcome. A fter all, DPAs are currently cheap for prosecutors and the proposed integrated approach would increase their cost. Costs must not be increased so much that DPAs are abandoned in favor of inferior choices such as the blunt and risky course of indictment. The concern should be modest, however, as the increased incremental costs, even if high at the outset, should decline over time as knowledge is developed, precedents built and procedures standardized. In any event, the effects of the switch might marginally reduce the number of DPA s over the short term, but their quality would increase with time as well.

Expertise or Competence. A second objection to the integrated approach concerns prosecutorial expertise or competence. $M$ any prosecutors lack training in corporate governance and some lack interest. Skeptics might thus wonder about the feasibility of calling for prosecutors to learn corporate governance, particularly of a large organization. This is a good objection to the status quo (featuring governance reforms without evident governance knowledge) but a weak point against the integrated approach. Again, walling off prosecutors from governance would discourage them from considering important facts ex ante. Further, while such a learning curve may be steep, it is climbable. The call, after all, is not so much about broad vague intangible notions of corporate culture but about particular governance attributes that contribute to defining it and then (a) what their presence says about the probable and desirable results of steps a prosecutor may consider and (b) what should be changed about them and why as a condition of settling a case. ${ }^{223}$

\footnotetext{
${ }^{221}$ One sample is the law review article that prosecutors published after executing a DPA with Bristol-M yers Squibb, in which they explained their rationale for many of the governance provisions and other terms. Christie \& Hanna, supra note 7; infra Apps. A and B.

${ }^{222}$ Such opinions, which are publicly available, have been provided by such corporate law professors as J esse Fried (Harvard), J effrey Gordon (Columbia), Sean Griffith (Fordham) and D onald L angevoort (G eorgetown).

${ }^{223}$ Further, the DOJ is seeking to systematize and coordinate internal knowledge and expertise concerning governance in DPAs. See supra text accompanying note 205. DOJ also increasingly seeks to coordinate with relevant agencies. See supra note 75 .
} 
Even so, at the DPA negotiation stage, a target board's and management likely have greater expertise and knowledge compared to prosecutors concerning governance terms generally and how they might work at their company. Prosecutors should recognize that and proceed with a degree of deference, though they do not always appear to do so. The articulation practice would improve the dialogue and the sense of shared good faith each side brings to the goal of improving governance. Care is particularly important, however, when settlements are negotiated with corporate officials after predecessors have been removed and replaced, as in the case of AIG. Perverse incentives may lead such continuing personnel to amplify concerns in a bid to cast all blame on outgoing executives. 224

In the end, however, corporate governance is not more sophisticated or inaccessible than any other peculiar subject with which prosecutors must contend. It is broader than compliance, but even compliance requires expertise that many prosecutors will not automatically have ahead of a case where it becomes necessary. Prosecutorial resources will increase with time, moreover, as prosecutors develop accessible precedents as reservoirs of knowledge. For those prosecutors unwilling or unable to learn what is required, they can enlist the aid of experts, from among current or former securities regulators, corporate law or business professors and the like. Caution must still be exercised, of course, as experts are not immune from mistakes, as the case of AIG attests, when a prominent former chairman of the SEC prescribed off-the-rack reforms that backfired due to improper evaluation of the company's corporate governance profile. ${ }^{225}$

Temperament. A variation on the objection about competence or expertise concerns institutional and personal disposition. Prosecutors may tend to be interested in-and institutionally directed-toward-punishment, usually via convictions and fines, and adopting an adversarial outlook. The integrated approach differs, as it embraces a more corporate transactional-bargaining and creative problem-solving approach. Even were chief prosecutors to require such exercises, given prosecutors may not be particularly good at them. On the other hand, the DPA setting marks at least an incremental retreat from the courtroom to the boardroom and thus a shift in outlook from hostility to settlement. Prosecutors inclined to carry such adversarial traits into the bargaining process are better advised to enlist the leadership of prosecutorial colleagues more disposed to the transactional approach to settlement. ${ }^{226}$ It is akin to the shift other disputatious types must undergo when opting for other forms of alternative dispute resolution. ${ }^{227}$

Potency. Even assuming prosecutors embraced the profile exercise and produced the articulations, there is no way to know how useful they would be. The product relies upon highly intangible incentives and there is no formal scrutiny. Formal scrutiny could be supplied by judges, as noted, but that solution, while potentially adding discipline, would also inflate costs and increase risks of error due to oversight by an individual who may lack expertise and institutional resources to provide it.

Furthermore, though intangible, prosecutors have their reputations at stake in the articulation exercise. That may provide a more serious constraint than judicial review, as it exposes prosecutors to the judgment of their peers and other professional and public

\footnotetext{
${ }^{224}$ See supra note 160.

${ }^{225}$ See supra text accompanying notes 128-147.

${ }^{226}$ See William F. Coyne, J r., The Case for Settlement Counsel, 14 OHIO ST. J. ON DISP. RESOL. 367 (1999).

${ }^{227}$ See Gary M endelsohn, N ote, Lawyers As Negotiators, 1 HARV. N EGOTIATION L. REV. 139 (1996).
} 
audiences. ${ }^{228}$ In addition, these documents would likely be drafted not solely by prosecutors but with considerable input from defense counsel resulting in a more meaningful and comprehensive product. $^{229}$

There is some risk that such follow-the-leader practices could simply produce a boilerplate product but boilerplate is often a sign of optimal contracting. ${ }^{230}$ Degenerative repetition would produce thoughtless boilerplate with prosecutors simply going through the motions, copying the last DPA memo released. If that were to occur, there would be little in lost costs along the way, however. It is a typical risk of failure not an objection that should prevent embracing the proposal.

Window Dressing. A final potential objection is that prosecutorial focus on governance will simply lead corporations to adopt best practices in name only, akin to how companies go through the motions of compliance without promoting legal obedience in fact. ${ }^{231}$ When corporations know that prosecutors focus on compliance when evaluating how to proceed with a case and settle it, a propensity toward compliance window dressing rises. ${ }^{232}$ The same concern is less likely valid concerning governance reforms.

Ex ante, prosecutorial examination of governance features encompasses such intangibles as the tone at the top and power allocations among officers, directors, employees and shareholders. Such features, unlike many compliance programs, are difficult to fake. The creation and maintenance of an employee stock ownership plan, for example, directly affects an important aspect of governance yet managers are unlikely to be able to manipulate it solely for cosmetic purposes. Nor can managers as readily manipulate such factors as the concentration of institutional shareholder ownership, ownership by insiders or employee culture.

On the other hand, prosecutors must avoid the best practices trap that wreaked havoc in the AIG case. A nother example of the problem, which befell the most devoted governance watchers, is how Enron's board was named among the best in A merica ${ }^{233}$ - just months before Enron was exposed to be a cipher.

\section{SPECIFIC Terms ANd BRISTOL-M YeRs SQUibB}

This Part considers examples of specific governance terms that have appeared or may appear in DPAs. Examples are drawn from numerous DPAs, including several from the controversial Bristol-M yers Squibb DPA. ${ }^{234}$ Additional details concerning that DPA appear in the Appendices, excerpting selected governance terms from it followed by prosecutorial explanations of those terms. The point is to illustrate the feasibility of this A rticle's prescription and some of the immediate benefits apparent from the exercise. It also suggests the value that might arise from the production of libraries or catalogues of similar articulations. Discussion in this Section also considers objections to specific terms' inclusion in DPAs as well as reasoning

\footnotetext{
${ }^{228}$ See Fred C. Zacharias, Effects of Reputation on the Legal Profession, 65 W ASH. \& LEE L. REV. 173 (2008).

${ }^{229}$ The practice of articulating rationales would have effects on the bargaining process as well. See Russell K orobkin \& Chris Guthrie, Heuristics and Biases at the Bargaining Table, 87 M ARQ. L. REV. 795, 800 (2004). Exploration of such phenomena and their implications are beyond the scope of this A rticle.

${ }^{230}$ See Symposium, Boilerplate: F oundations of Market Contracts, 104 M ICH. L. REV. (2006).

${ }^{231}$ See supra text accompanying note 65.

${ }^{232}$ Id.

${ }^{233}$ Robert W. Lear, Boards on Trial, Chief ExeCUtIVe (October 31, 2000).

${ }^{234}$ Christie \& Hanna, supra note 7.
} 
to justify such inclusion. ${ }^{235}$ These justifications are illustrative of the rationales prosecutors should publicly provide when including these terms in DPAs.

\section{A. 0 fficers and Directors}

It is common for DPAs to call for the termination of employment of particular individuals, often officers alleged to have been involved in wrongdoing. The AIG case study provided the ultimate example of such an effort, targeting a CEO. Though common, the DPAs and accompanying press releases usually reveal little about the rationale of these changes. Critics oppose allowing DPAs to require such terminations. ${ }^{236}$ After all, officers are appointed by directors, and that appointment is among the most important jobs a board performs. It is considered an inviolate mandate as seen in criticism of Spitzer for overtly engineering the ouster of the CEO at $M$ arsh \& MCLennan ${ }^{237}$ and the more covert effort at A IG.

Such ouster would be objectionable when a prosecutor has not made a careful good faith study of the claims being lodged, as a legal matter. To justify it, prosecutors also should be willing to explain their actions from a corporate governance perspective. Such judgments must be based on an investigation, not made before investigation, as was done in A IG's case. Probable cause is a concept of criminal procedure relevant to an ex ante determination about whether to proceed, not the standard for corporate governance ouster, which is a business judgment that must be based on reliable information not ex ante probabilities. ${ }^{238}$

$M$ any DPAs also prescribe specific structural or organizational attributes for certain officer positions, a topic of corporate governance usually left up to boards. M ost commonly, DPAs require the appointment of particular officers, such as chief compliance officers or chief risk officers. Some direct particular reporting protocols, such as that the officer may not report to the CEO or other management but directly to the board or a subset of the board. Prosecutors may seek to separate the identity of the CEO and chairman. (All these were included in the AIG prosecution.)

Any or all of these may have a defensible logic in the context of a given company's overall corporate governance attributes. It ought to be permissible for prosecutors, so long as they have demonstrated an understanding of those attributes and articulate a rationale for the terms, to negotiate for them or even impose them. For example, at B ristol-M yers Squibb, prosecutors requested that the chairman and CEO positions be split. Although the rationale was not articulated as part of the agreement when executed, the prosecutors subsequently published a law review article in which they offered an explanation. ${ }^{239}$ It may not be as detailed as one would

\footnotetext{
${ }^{235}$ Discussion speaks in terms of the corporate form but should be applicable generally to other forms of business organization. It is an illustrative survey rather than an exhaustive inventory, as the subject of corporate governance is vast. It also addresses only cognizable terms, omitting those that cannot be altered by an agreement as a practical matter, such as concerning shareholder demographics, as well as those that are restricted for other legal reasons, such as upsetting settled and reasonable employee expectations concerning indemnification or advancement of expenses to those facing legal claims. Cf. U nited States v. Stein, 541 F.3d 130 ( ${ }^{\text {nd }}$ Cir. 2008) (endorsing employee objection, on constitutional grounds, to prosecutorial insistence that corporation refuse to cover employees' legal defense expenses).

${ }^{236}$ E.g., Arlen \& K ahan, supra note 89.

${ }^{237}$ See supra text accompanying note 117.

${ }^{238}$ See Smith v. Van G orkum, 488 A .2d 858 (Del. 1985).

${ }^{239}$ Christie \& Hanna, supra note 7.
} 
hope, but it reassuringly demonstrates awareness of important issues and a struggle with balancing trade-offs within the company:

[The traditional structure of having the top leader hold both positions] has its own benefits and risks: a strong chair/CEO is quite likely a more efficient structure than splitting the jobs, yet it provides fewer checks and balances. . . . [It can be valuable to] have an active, experienced non-executive chairman act as an effective check on the CEO and to insure that the CEO's office would not act as a bottleneck for information between the corporate offices and the board of directors. We believed that this change would enhance the openness and effectiveness of the governance of B ristol-M yers [Squibb]. Eventually, management agreed with our assessment. ${ }^{240}$

This discussion might have offered additional specific reasons to believe why splitting the roles would be effective at Bristol-M yers Squibb, both in terms of compliance and performance. Such explanations should accompany the DPA, not be published afterwards. Despite such shortcomings, articulation of rationales is unusual, attractive and worthy of emulation.

The board of directors is at the core of corporate governance entailing many attributes such as size, qualification, term of office, use of committees and executive sessions. Skeptics would oppose terms in any of these quintessential topics of corporate governance, though many DPAs contain such "intrusions." For example, several have required the board to add one or more outside directors. ${ }^{241}$ In the case of Computer Associates, the DPA named the particular person who would serve- Laura Unger, a former SEC Commissioner. In at least one case, the agreement provided for the reinstatement of a particular individual. ${ }^{242}$ The addition of numerous outside directors at AIG was also done in part by prosecutorial instigation.

Some might object that it is unlikely that adding any given number of directors, or filling the slots with one or more additional outside directors, would have any bearing on a corporation's propensity toward compliance with law or add deterrence. ${ }^{243}$ But such sweeping generalities are hard to defend. It is possible that the management directors on a given board have outsized influence to emphasize risk-taking and err too often on the side of legal violations and that, had there been just one more outside voice objecting to such a view, a different atmosphere or culture could develop.

It is even possible, in principle, that an agreement between a prosecutor and corporation on the designation of a particular person is defensible. ${ }^{244} \mathrm{That}$ is especially logical in the case of

\footnotetext{
${ }^{240}$ Id. at $1051-52$.

${ }^{241}$ B ristol-M yers Squibb (2005) (add two outside directors); Friedman's, Inc. (2005) (firm must have number of independent directors required by NY SE).

${ }^{242}$ A B B V etco Gray (Feb 2007) (reappointment of a new executive chair to the board).

${ }^{243}$ A rlen $\&$ Kahhan, supra note 89.

${ }^{244}$ Critics fairly object to the naming of particular people or organizations in DPA s on the grounds that doing so may create the appearance of cronyism. At minimum, it seems desirable for prosecutors to refrain from dictating any particular donation or naming any given person to assume any role. If such terms are deemed desirable in good faith based on an assessment of corporate governance realities, then prosecutors should repose discretion over the particulars to the company rather than specify a particular person or organization. To reduce doubt, prosecutors
} 
a term calling for the reinstatement of a particular individual, as experience provides observable evidence of probable effectiveness. Of course, one should not have to take it on faith that such terms are ipso facto legitimate. But prosecutors should be entitled to agree to such terms, provided they considered governance realities and explain the basis for including them in written rationales accompanying the DPAs.

DPAs may call for the creation of particular committees, and their various attributes. Notably, neither federal nor state law requires any corporate board to have committees. ${ }^{245}$ The closest to a mandatory committee arises from Sarbanes-0xley which sets stringent requirements for any audit committee that exists and then provides that if there is no separate audit committee then the stringent requirements apply to the whole board. ${ }^{246} \mathrm{~A}$ similar effect arises from the Dodd-Frank Act to produce compensation committees. ${ }^{247}$ Governance devotees and institutional shareholders also often seek or endorse the creation of other committees at particular companies, including governance and nomination committees.

Some DPAs have followed suit. ${ }^{248} \mathrm{~A}$ good example is the DPA with Gen Re, the Berkshire Hathaway subsidiary at the origin of the AIG case, which required Gen Re's audit committee meetings to be attended by an officer of Berkshire Hathaway. ${ }^{249}$ There may be a credible rationale for this: Berkshire, thanks largely to Warren Buffett, exudes corporate integrity. ${ }^{250}$ It had recently acquired $\mathrm{G}$ en Re and found that there was a gap between Berkshire's traditional tight internal control environment and looser practices at Gen Re. ${ }^{251}$ This is a quintessential governance issue, both in terms of the implicit knowledge of the need and the remedy, but with a coherent rationale. The principal defect is that the prosecutor failed to publicly articulate that rationale.

\section{B. C haritable Giving}

Corporate charitable giving is a feature of corporate governance that prosecutors sometimes use when forming DPAs ${ }^{252}$ Terms usually involve a corporate commitment to contribute funds to designated organizations. Some critics object to such commitments because, on their face, they are remote from any agency costs of internal corporate policing. Other critics see prosecutorial overreaching when they perceive that the charity is one that the prosecutor personally favors. It is obviously indefensible for a prosecutor to propose terms designed to

might forbid naming any persons or institutions with which anyone in the prosecutors' office is associated. A credible middle ground might allow for the corporation to choose from a list that the prosecutors pre-approves

${ }^{245}$ State statutes invariably permit but do not require board committees. E.g., DEL. GEN. CORP. L. § 141(c)(2).

${ }^{246}$ Sarbanes-Oxley Act, § 301.

${ }^{247}$ D odd-Frank A ct, $\S 952$.

${ }^{248}$ E.g., Friedman's, Inc. (2005) (requiring firm to create audit, nomination and compensation committees); Computer A ssociates (2004) (requiring committees and an extensive array of other governance changes).

${ }^{249} \mathrm{Gen} \operatorname{Re}$ (2009).

${ }^{250}$ E.g., ANDREW K ILPATRick, W ARren Buffett: The GoOd Guy OF W All Street (1995).

251 This is evident from reading selections from B uffett's annual letters to Berkshire Hathaway shareholders during the period from 2000 to 2006. See W arren E. Buffett \& LaWrence A. CunNingham, The EsSays of W ARren BUfFETT: LESSONS FOR CORPORATE AMERICA (2d ed. 2007).

252 The issue of charitable contributions has receded, as the DOJ and OSG discourage the practice. But it is worth questioning why. Under the analysis in this Article, there is nothing that warrants excluding the topic from consideration in a DPA. The DOJ and OSG discouragement may be unwarranted reaction to critical objections that miss the mark. 
advance personal interests. ${ }^{253}$ Such donations may be consistent with the existing corporate governance or have another defensible purpose, but it is up to the prosecutor to provide the reasoning and quiet the critics.

Critics often cite the Bristol-M yers Squibb deal as an example of a required donation amounting to an abuse of prosecutorial discretion. They single out the requirement that the company endow a chair in legal ethics at Seton Hall University Law School, from which the prosecuting attorney graduated. ${ }^{254} \mathrm{~B}$ ut the prosecutors report that the requirement was made in general terms, to promote ethical training of company executives, and the only restriction was geographic - that it be done in N ew J ersey, location of its headquarters. ${ }^{255}$ The other law schools in New Jersey al ready had a program. Management chose Seton Hall-after the DPA was done. $^{256}$ This explanation negates the charge of parochialism and adds a compliance-oriented rationale of providing related training to company personnel. ${ }^{257}$

A $n$ important factor to consider about charitable donations is the relationship between a company's existing governance philosophy concerning charitable giving and the donation. Some companies have a tradition of corporate charitable giving, while others do not, and those traditions should inform judgments about such terms in DPAs. As examples, companies including AIG and Berkshire Hathaway historically foreswore using corporate resources for charitable purposes, both stressing that the boards believed that such allocations were the prerogative of shareholders. ${ }^{258}$ But other corporations, including B ristol-M yers Squibb, follow a different philosophy and routinely make such contributions. Corporate charitable giving at $B$ ristol-M yers Squibb included an entire category devoted to professorships and related academic positions. ${ }^{259}$ While the DPA was thus consistent with past practice at B ristol-M yers Squibb and appropriate as a matter of corporate governance there, such a term at A IG or B erkshire Hathaway would have been inconsistent with their particular practices and therefore inappropriate.

Prosecutors ought to be able to demonstrate at least some logical link between the corporation and its alleged wrongdoings and the related charitable cause. A doubtful example appeared in the case of the DPA with Operations M anagement International. ${ }^{260}$ It was alleged to have violated environmental laws. Its DPA called for it to donate to the Alumni A ssociation of the Coast Guard A cademy to endow a chair in environmental studies. Without an explanation,

\footnotetext{
${ }^{253}$ See Green \& Zacharias, supra note 184 at 856-58.

${ }^{254}$ E.g., Arlen \& Kahhan, supra note 89; Albert W. Alschuler, Two Ways to Think About the Punishment of Corporations, 46 A M. CRIM. L. Rev. 1359, 1384-85 (2009); Spivack \& Raman, supra note 81 at 174 (textual presentation of term as objectionable along with a footnote citing other sources explaining its possible legitimacy).

${ }^{255}$ See Christie \&. Hanna, supra note 7.

${ }^{256} \mathrm{Id}$.

${ }^{257}$ A more prudent approach would be for the prosecutor to forbid targets from naming given institutions with which the prosecutors' office is associated. See supra note 244.

${ }^{258}$ See Greenberg \& CUNnINGHAM, The AIG STORY, supra note 104 (AIG): BuffetT \& Cunningham, supra note 251 (B erkshire Hathaway), at 62 (§ I.E "An Owner-Based A pproach to Corporate Charity"). M any AIG directors made charitable giving by endowing private foundations dedicated to their preferred causes. Neil Starr had begun that practice, endowing a foundation of modest size that, concentrated in AIG stock, would grow over three decades after his death to several billion dollars. Other directors, including B uck Freeman, Hank Greenberg, J immy M anton and Ernie Stempel, followed suit by establishing private foundations to make charitable gifts, which aggregated to billions of dollars. Greenberg \& CUNnINGHAM, The AIG StORY, supra note 104. At Berkshire, Warren Buffett famously contributed virtually his entire net worth to charitable causes, including via the Gates Foundation. BUFFETT \& CUNNINGHAM, supra note 251.

${ }^{259}$ See B ristol-M yers Squibb web site at http://www.bms.com/responsibility/grantsandgiving/Pages/default.aspx.

${ }^{260}$ Operations M anagement I nternational DPA (D. Conn. 2006).
} 
there is no obvious logical connection between the alleged violations and that particular organization or between the alleged violations and the prospect of improvement.

A similar opacity problem afflicted the DPA with Gibson Guitar Corp. It allegedly violated the Lacey Act, and foreign laws, restricting the use of certain wood. Gibson allegedly acquired certain protected wood unlawfully for use in the fingerboards of the guitars it manufactured. In addition to a fine and compliance commitments, the DPA required the company to donate $\$ 50,000$ to the National Fish and W ildlife Federation. ${ }^{261} \mathrm{~N}$ either the DPA nor accompanying materials explain the rationale for that donation. There may be a defensible logic to this but without an explanation critics have an easy target to object to this term. ${ }^{262}$

\section{M onitors and Consultants}

M onitors have theoretical appeal as an oversight mechanism to assure compliance with the agreed terms of DPA s. ${ }^{263} \mathrm{~A}$ bsent some such mechanism, violations could go undetected. $Y$ et there is also room for abuse, as when cronyism dominates the selection process and additional agency costs plague the monitors. Critics cite a series of monitor appointments, made without any bidding process, by the then U.S. A ttorney in N ew J ersey, Christopher Christie, including in the case of Bristol-M yers Squibb. The DOJ has addressed some of these concerns through express guidance on the subject but the use of monitors remains of uncertain value. ${ }^{264}$

In A IG's case, a monitor was installed at its financial products division (FP) in late 2004, a few months before $\mathrm{G}$ reenberg resigned. ${ }^{265}$ Initially charged with assuring that customers would not use FP products primarily to massage their books, the assignment gradually expanded over ensuing years after Greenberg left AIG to encompass broader aspects of FP's transactions and internal controls. The monitor spent 2005, 2006, and 2007 submitting to the SEC and management periodic confidential reports on a wide range of topics in accounting, compliance and disclosure. AIG paid $\$ 20$ million for these services. ${ }^{266}$ The monitor apparently did not discover or report to AIG's board or senior management the brewing problems at FP that contributed to the financial crisis of $2008 .{ }^{267} \mathrm{M}$ onitors can be ineffective, despite being costly. ${ }^{268}$

\footnotetext{
${ }^{261}$ DOJ -Gibson Guitar Corp. DPA (J uly 27, 2012), available at http://lib.law.virginia.edu/Garrett/prosecution agreements/pdf/Gibson_Guitar.pdf.

${ }^{262}$ For example, it is possible to classify the Gibson Guitar donation as akin to community service that judges sometimes impose when sentencing defendants after conviction. A prosecutors' explanation would be better than a professor's speculation, however.

${ }^{263}$ See Christie Ford \& David Hess, Can Corporate M onitorships Improve Corporate Compliance?, 34 J. CORP. L. 679 (2009); V ikramaditya K hanna \& Timothy Dickinson, The Corporate M onitor: The New Corporate Czar?, 105 M ICH. L. REV. 1713, 1737 (2007) (urging "greater specificity in the DPA about the tasks and powers of monitors").

${ }^{264}$ Craig M oreford, M emorandum to Heads of Department Components and U.S. A ttorneys: Selection and U se of M onitors in Deferred Prosecution A greements and Non-Prosecution A greements with Corporations (M arch 7, 2008) http://www.justice.gov/dag/morford-useofmonitors memo-03072008.pdf; Gary G. Grindler, M emorandum to Heads of Dep't Components: A dditional Guidance on the U se of M onitors in Deferred Prosecution A greements and N onProsecution Agreements with Corporations (M ay 25, 2010), http://www.justice.gov/dag/dag-memo-guidancemonitors.html.

${ }^{265}$ See supra note 113.

${ }^{266}$ See Peter Lattman, The U.S.' s Fly on the Wall at AIG, N.Y. TIM ES (M arch 27, 2009); Consent Order 9 3.a.1

267 See Memorandum from Mark Jickling to the House Committee on Oversight and Government Reform, Independent Consultant Reports on AIG A ccounting Reforms, Congressional Research Service (M ay 5, 2009); SEC V. AIG (D. D. C. A pril 16, 2012) (opinion granting motion to compel disclosure of the reports by journalist Sue Reisinger of Corporate Counsel), available at http://pdfserver.amlaw.com/cc/K esslerFOI_opinion.pdf.
} 
Such failures, along with aversion to accusations of cronyism, may explain why the use of monitors in DPAs has declined lately. For instance, in the mid-2000s, almost all DPAs required a monitor whereas in recent years only about one-third do. ${ }^{269}$ Other alternatives may avoid such pitfalls and be more effective for given companies. A $n$ exquisite example appears in the DPA with Gen Re, the Berkshire Hathaway subsidiary. The requirement (noted above) ${ }^{270}$ that a Berkshire official attend all Gen Re audit committee meetings installs a functional monitor employed by the parent company, providing reliable oversight in a logical governance fit.

Many DPAs require a company to hire a consultant charged with recommending governance changes. Terms often require the company to accept the directives except on the approval of the governmental authority. Potential changes may be extremely broad and include any number of provisions addressing every aspect of compliance and all parts of corporate governance. The AIG DPA had such a clause requiring retaining a consultant and accepting all changes. ${ }^{271}$ That appears to be an enormous vesting of discretion in a person whose authority would be final and unreviewable by any third party. This is objectionable on prudential grounds. The call for prosecutorial investigation ex ante and articulation ex post should contribute a sense of competence to enable prosecutors to curtail that discretion, either by accelerating the reporting and recommendation phase or actively supervising any consultant that may remain necessary.

\section{Shareholders and Disclosure}

A nother objection to including governance terms in DPA $s$ is that certain terms are of vital importance to shareholders and over which they should have some say. In accordance with state corporation law, some of these terms require shareholder approval. One way to address this valid concern is to broaden the range of corporate governance terms that can be in DPAs to include shareholder votes for certain terms. This would draw on the usual rules of corporate law for use in the real $m$ of criminal justice administration. ${ }^{272}$

State corporation law usually vests shareholders with voting power over charter amendments that might define certain board attributes such as size and director election rules. It may be desirable in some cases to consider shareholder votes on other matters typically within a board's discretion, such as committee types, meetings, and attendees; or management, such as reporting lines. A small number of topics might even require a shareholder vote under federal law - such as the approval of a company's outside auditors.

Shareholder voting would both empower shareholders, recognizing their role in corporate governance that their economic interest affords, and reveal information relevant to prosecutorial decision making on how to proceed. Giving shareholders such a voice mutes criticism of unilateral prosecutorial or managerial action. It would also enhance the integrity of the process and increase the capacity of observers to evaluate the legitimacy of its procedures and the results.

DPA s invariably require a corporate target to provide public disclosure of various kinds. These routinely include disclosure concerning the circumstances leading to the DPA and related

\footnotetext{
${ }^{268}$ See Lisa K een Griffin, Inside-Out Enforcement, in BARKow \& BARKOW, PROSECUTORS IN THE BOARDROOM, supra note 1, at 121-122 (criticizing monitor in A IG case).

${ }^{269}$ A rlen \& K ahan, supra note 89 (84\% 2003-05 versus 35\% 2008-2010).

${ }^{270}$ Supra text accompanying notes $249-251$.

${ }^{271}$ See supra text accompanying notes 130-134.

272 See M iriam Hechler Baer, O rganizational Liability and the Tension between Corporate and Criminal Law, 19 J.

L. \& POL'Y 1 (2011).
} 
allegations. Other DPAs call for maintaining enhanced standards relating to disclosure in the interest of increasing the corporation's transparency. Disclosure is an integral part of corporate governance and can also be a stimulant to promote compliance.

Critics have not challenged inclusion of disclosure terms in DPAs and it would be difficult to sustain such a critique when the disclosure concerns management's discussion and analysis of such matters as the DPA's circumstances and ongoing business operations. As a matter of corporate governance, however, some restraint is advisable to assure that a DPA's disclosure requirements gel with existing corporate practices concerning disclosure, such as the form and timing of communications to shareholders. Within the framework of securities and corporate laws concerning disclosure, companies adopt varying stances on how often or how much detail to supply to shareholders, and scholars debate the optimal level of disclosure. ${ }^{273}$

\section{CONCLUSION}

Prosecutors targeting corporate defendants may give insufficient consideration to corporate governance when exercising discretion over how to proceed. Y et such factors are vital to both the process pursued and settlements reached at the end. They should therefore consider such variables as shareholder demographics, board orientation, executive reporting, employee incentives and other factors that bear on how any given formal corporate governance structure operates. Prosecutors who heed governance at the outset both earn credibility to include such terms in resolution, and are likelier to propose more effective, narrowly tailored terms. Failure to investigate first can have devastating consequences, as cases such as A rthur Andersen and A IG suggest. Investigation and articulation would produce clear benefits, including increased legitimacy of DPA s ex post, neutralizing criticism aimed at many DPAs.

The DOJ should update its guidelines to encourage prosecutors to consider governance at the outset and to provide such explanations. Other prosecutorial leaders nationwide should follow suit. To be sure, this prescription would not necessarily guarantee better outcomes. For example, had prosecutors taken heed at AIG and viewed the governance realities starkly, they still may have decided to impose all the changes actually imposed on the grounds that they judged that such a radical overhaul was necessary. True, but consideration would increase the chance of desirable outcomes. This problem reflects the challenge of working within a framework of discretion. There will always be some risk of error. While not guaranteed, this integrated approach is better than the status quo. A fter all, had prosecutors studied A ndersen in the prescribed way, a better outcome is highly likely.

In short: the proposal recognizes the proliferation of DPAs as a novel form of corporate criminal justice administration that would benefit from being formalized, systematized and catal ogued, rather than maintained in the black box of traditional prosecutorial discretion.

${ }^{273}$ See Troy A. Paredes, Blinded by the Light: Information Overload and its Consequences for Securities Regulation, 81 W ASH. U. L. Q. 417 (2003). 


\section{A PPENDICES}

A. B ristol-M yers Squibb Deferred Prosecution A greement

B. Prosecutors' A rticulations on B ristol-M yers Squibb DPA 


\section{A. Bristol-M yers Squibb Deferred Prosecution Agreement}

The following are excerpts from the DPA dated June 15, 2005 between Bristol-M yers Squibb ("BM S") and the U.S. Department of J ustice, District of New J ersey (referred to as the "Office") arising out of alleged accounting violations concerning the timing, measurement and disclosure of transactions that had the effect of premature recognition of revenue. A ppendix B excerpts prosecutorial explanations, addressing most of the following directly.

5. BMS has undertaken extensive reforms and remedial actions in response to the conduct at BMS that is and has been the subject of the investigation by the Office. These reforms and remedial actions have included:

(a) Retaining the Honorable Frederick B. Lacey as Independent Advisor, to conduct a comprehensive review of the implementation and effectiveness of the internal controls, financial reporting, disclosure, planning, budget and projection processes and related compliance functions of the Company, as well as to serve additional supervisory and monitoring functions described herein; ...

(d) Making significant personnel changes .... after the Office commenced its investigation including: (i) replacing the former Chief Financial Officer (CFO); (ii) replacing the former President of the Worldwide Medicines Group; (iii) replacing the former Controller; (iv) establishing the position of Assistant Controller for Financial Compliance and Control; (v) establishing the position of Chief Compliance Officer; (vi) establishing a position for an experienced securities regulation and disclosure lawyer who has a significant role in all BMS disclosure responsibilities;

(e) Changing its budget process, to assure that appropriate consideration is given to input and analysis from the bottom to top, and not exclusively from top to bottom, and adequately documenting that process;

( $f$ ) Forming a business risk and disclosure group that includes senior management, the Independent Advisor and counsel to the Independent Advisor;

(g) Identifying and implementing actions to improve the effectiveness of its disclosure controls and procedures and internal controls, including enhancing its resources and training with respect to financial reporting and disclosure responsibilities, and reviewing such actions with its Audit Committee and independent auditors;

(h) Implementing a formal review and certification process of its annual and quarterly reports filed with the Securities and Exchange Commission (SEC); and

(i) Providing an effective mechanism in the form of a confidential hotline and e-mail address, of which BMS employees are informed and can use to notify BMS of any concerns about wholesaler inventory levels or the integrity of the financial disclosures, books and records of BMS....

8. BMS shall establish the position of non-executive Chairman of the BMS Board of Directors (the "Non-Executive Chairman"), to advance and underscore the Company's commitment to exemplary corporate citizenship, to best practices of effective corporate governance and the highest principles of integrity and professionalism, and to fostering a culture of openness, accountability and compliance throughout the Company. BMS shall retain the position of Non-Executive Chairman at least throughout the term of this Agreement.

9. BMS agrees to appoint an additional non-executive Director acceptable to the Office to the BMS Board of Directors within sixty (60) days of the execution of this Agreement.

10. The Company's CFO, General Counsel, and Chief Compliance Officer regularly shall brief and provide information to the Non-Executive Chairman, in a manner to be determined by the Non-Executive Chairman. In addition, the Non-Executive Chairman shall have the authority to meet with, and require reports on any subject from, any officer or employee of the Company. 
11. BMS agrees that until at least the date of the filing of the Company's Form 10-K for the year ended 2006, it will retain an outside, independent individual or entity (the "Monitor"), selected by BMS and approved by the Office. BMS may employ as the Monitor the Honorable Frederick B. Lacey. It shall be a condition of the Monitor's retention that the Monitor is independent of BMS and that no attorney-client relationship shall be formed between the Monitor and BMS.

12. The Monitor shall: (a) Monitor BMS's compliance with this Agreement, and have authority to require BMS to take any steps he believes are necessary to comply with the terms of this Agreement; (b) Continue the review, reforms and other functions undertaken as the Independent Advisor; (c) Report to the Office, on at least a quarterly basis and between thirty and forty-five calendar days after the filing of the Company's Form 10-K for the year ended 2006, as to BMS's compliance with this Agreement and the implementation and effectiveness of the internal controls, financial reporting, disclosure processes and related compliance functions of the Company. ... (d) Cooperate with the SEC and provide information about BMS as requested by that agency; (e) Monitor BMS's compliance with applicable federal securities laws, and in his quarterly reports make recommendations necessary to ensure that the Company complies with applicable federal securities laws; ... .

13. BMS agrees that the Chief Executive Officer (CEO), Non-Executive Chairman, and General Counsel will meet quarterly with the Office and the Monitor, in conjunction with the Monitor's quarterly reports.

14. BMS shall adopt all recommendations contained in each report submitted by the Monitor to the Office unless BMS objects to the recommendation and the Office agrees that adoption of the recommendation should not be required. The Monitor's reports to the Office shall not be received or reviewed by BMS prior to submission to the Office; such reports will be preliminary until senior management of BMS is given the opportunity, within ten (10) days after the submission of the report to the Office, to comment to the Monitor and the Office in writing upon such reports, and the Monitor has reviewed and provided to the Office responses to such comments, upon which such reports shall be considered final.

17. The Non-Executive Chairman and the Compensation Committee of the Board of Directors shall set goals and objectives relevant to compensation of the CEO, evaluate the CEO's performance in light of those goals and objectives, and recommend to the Board of Directors compensation based on this evaluation.

18. BMS agrees that it will establish and maintain a training and education program, which shall be reviewed and approved by the Board of Directors, designed to advance and underscore the Company's commitment to exemplary corporate citizenship, to best practices of effective corporate governance and the highest principles of integrity and professionalism, and to fostering a culture of openness, accountability and compliance throughout the Company.... The Board of Directors shall communicate to the Mandatory Participants, in writing or by video, its review and endorsement of the training and education program....

20. BMS shall endow a chair at Seton Hall University School of Law dedicated to the teaching of business ethics and corporate governance, which position shall include conducting one or more seminars per year on business ethics and corporate governance at Seton Hall University School of Law that members of BMS's executive and management staff, along with representatives of the executive and management staffs of other companies in the New Jersey area, may attend. . . .

22. Within thirty (30) days of the execution of this Agreement, BMS agrees to call a meeting, on a date mutually agreed upon by BMS and the Office, of its senior executives and any senior financial personnel, and any other BMS employees who the Company desires to attend, such meeting to be attended by the United States Attorney and other representatives of the Office for the purpose of communicating the goals and expected effect of this Agreement. 
23. For a period of one year from the execution of this Agreement, the Non-Executive Chairman, CEO, and General Counsel shall contemporaneously monitor either in person or telephonically BMS's quarterly conference calls for analysts ("analyst calls"), and the Non-Executive Chairman shall attend and participate in any preparatory meetings held among the CEO, the CFO, the General Counsel and other members of BMS senior management in anticipation of the analyst calls. The General Counsel shall ensure that representatives of the BMS legal division are informed and consulted regarding, at a minimum, issues relating to disclosure or securities law that may arise in the course of preparing for the analyst calls.

24. The CEO and CFO shall prepare and submit to the Non-Executive Chairman, Chief Compliance Officer and the Monitor described in paragraph 11 written reports on the following subjects: (a) all non-standard transactions with major U.S. wholesalers, such written report to be submitted within fifteen (15) days of such transaction; (b) an overview and analysis of BMS's annual budget process for its major business units, including description of significant instances of any top-down changes to business unit submissions, such written report to be submitted together with the proposed budget submitted for approval to the Board of Directors; (c) sales and earnings forecasts or projections at the corporate or major business unit level which indicate a quarterly target will not be met, together with a description of steps subsequently taken, if any, to achieve the budget target, such written report to be submitted quarterly and at least ten (10) business days prior to the Company's scheduled quarterly analyst call; d) description of significant instances in which the preliminary quarterly closing of the books of any major business unit indicated that the business unit would not meet its budget target for any sales or earnings measure.

25. BMS agrees that it shall include in its quarterly and annual public filings with the SEC and its annual report to shareholders financial disclosures concerning the following: (a)(i) for the Company's U.S. Pharmaceuticals business, estimated wholesaler/direct-customer inventory levels of the top fifteen (15) products sold by such business and (ii) for major non-U.S. countries, estimated aggregate wholesaler/direct-customer inventory levels of the top fifteen (15) pharmaceutical products sold in such countries taken as a whole measured by aggregate annual sales in such countries; (b) arrangements with and policies concerning wholesalers/direct customers and other distributors of such products, including but not limited to efforts by BMS to control and monitor wholesaler/distributor inventory levels; (c) data concerning prescriptions or other measures of end-user demand for such top fifteen (15) BMS pharmaceutical products sold within the U.S. and in major non-U.S. countries; (d) acquisition, divestiture, and restructuring reserve policies and activity; and (e) rebate accrual policies and activity. The CEO shall, at the annual BMS shareholder meeting, report to the shareholders on these topics.

26. BMS agrees that it will continue to review and improve, where necessary, the content of its public financial and non-financial public disclosures, including periodic SEC filings, annual and other shareholder reports, press releases, and disclosures during analyst conference calls, as well as during meetings with investors and credit ratings agencies. BMS agrees that it will at all times strive for openness and transparency in its public reporting and disclosures.

27. BMS shall encourage the free flow of information between its employees and its external auditor, and encourage its CFO and senior finance personnel to seek advice from the external auditor. The CEO, CFO, General Counsel, and Chief Compliance Officer shall meet quarterly with the Company's external auditors, such meeting to occur following the closing of the Company's books for the quarter and prior to the Company's scheduled quarterly analyst call. At the quarterly meeting, the BMS attendees shall discuss business and financial reporting developments, issues and trends with the external auditor, as well as provide information to the external auditor concerning the subjects described in paragraph 24 above, and shall respond to inquiries from the external auditor. 


\section{B. Prosecutors' Articulations on Bristol-M yers Squibb DPA}

The following are excerpts from the law review article, published in 2006, by prosecutors in the case of Bristol-M yers Squibb ("BM S") explaining some of the governance terms of the DPA excerpted in A ppendix A. ${ }^{274} \mathrm{Far}$ from perfect and perhaps not even optimal, it illustrates the relative ease of the exercise and suggests the potential value of articulations that, together, furnish considerable systemic benefits. The article also explained some of the background of the investigation, including highlights of the company's governance profile reflecting a degree of ex ante consideration of important factors.

One issue we faced was how to reverse Bristol-Myers' failures to disclose facts underlying its channel stuffing, accruals for rebates, and manipulation of reserves. The deferred prosecution agreement deals with the most obvious aspect of this problem by mandating specific disclosures in Bristol-Myers' public filings with the SEC and its annual report to shareholders [quoting \25 as follows]:

Bristol-Myers agrees that it shall include in its quarterly and annual public filings with the SEC and its annual report to shareholders financial disclosures concerning the following: (a)(i) for the Company's U.S. Pharmaceuticals business, estimated wholesaler/directcustomer inventory levels of the top fifteen (15) products sold by such business and (ii) for major non-U.S. countries, estimated aggregate wholesaler/direct-customer inventory levels of the top fifteen (15) pharmaceutical products sold in such countries taken as a whole measured by aggregate annual sales in such countries; (b) arrangements with and policies concerning wholesalers/direct customers and other distributors of such products, including but not limited to efforts by Bristol-Myers to control and monitor wholesaler/distributor inventory levels; (c) data concerning prescriptions or other measures of end-user demand for such top fifteen (15) Bristol-Myers pharmaceutical products sold within the U.S. and in major non-U.S. countries; (d) acquisition, divestiture, and restructuring reserve policies and activity; and (e) rebate accrual policies and activity. The CEO shall, at the annual Bristol-Myers shareholder meeting, report to the shareholders on these topics.

Requiring specific disclosures, however, is somewhat akin to treating the symptoms of a disease and not its causes. Therefore, we sought a more fundamental change in Bristol-Myers' attitude toward the investing public. To that end, the deferred prosecution agreement [in आ26] includes Bristol-Myers' commitment "that it will at all times strive for openness and transparency in its public reporting and disclosures" and "that it will continue to review and improve, where necessary, the content of its public financial and non-financial public disclosures, including periodic SEC filings, annual and other shareholder reports, press releases, and disclosures during analyst conference calls, as well as during meetings with investors and credit ratings agencies."

The deferred prosecution agreement also calls for Bristol-Myers to utilize the expertise of its outside auditors on disclosure and accounting matters [quoting $\{27$ as follows]:

Bristol-Myers shall encourage the free flow of information between its employees and its external auditor, and encourage its CFO and senior finance personnel to seek advice from the external auditor. The CEO, CFO, General Counsel, and Chief Compliance Officer shall meet quarterly with the Company's external auditors ... prior to the

\footnotetext{
${ }^{274}$ These selections are from Christie \& Hanna, supra note 7, at 1053-58.
} 
Company's scheduled quarterly analyst call. At the quarterly meeting, the Bristol-Myers attendees shall discuss business and financial reporting developments, issues and trends with the external auditor, as well as provide information to the external auditor concerning the subjects described in paragraph 24 , and shall respond to inquiries from the external auditor.

By including provisions relating to transparency, our intent was to address both specific failings uncovered in the investigation and an equally disturbing corporate culture that favored secrecy over openness. For example, by requiring regular quarterly meetings among senior management and their independent auditors, our expectation is that if future law breaking were to occur, it would be much more difficult for top management and the auditors to claim ignorance. The goal is that Bristol-Myers should report all material facts, good and bad, to the investing public. With respect to unfavorable news, BristolMyers must get into the habit of disclosure, not concealment; if there is a question about whether or not to disclose something, the deferred prosecution agreement clearly calls for more information, not less.

Perhaps the most difficult issue to address in this matter was reforming Bristol-Myers' corporate governance in ways that would give some assurance that the failures [we found] would not be repeated. At the very least, Bristol-Myers' remaining top management failed to detect and prevent the wrongdoing [we found]. Yet federal prosecutors must tread warily in the area of corporate governance. Plainly, federal prosecutors have no business telling corporate executives what business judgments to make or otherwise intruding into business decisions. It was clear to us, however, that Bristol-Myers' board of directors and top executives had to be more involved in governing the company and therefore more accountable to all its stakeholders. This greater involvement of top management, together with a healthy dose of outside oversight, would provide confidence that Bristol-Myers will not repeat past sins.

Bristol-Myers, like many U.S. companies, had historically allowed its top leader to hold both positions of chairman of the board of directors and chief executive officer (CEO). This structure undoubtedly has its own benefits and risks: a strong chair/CEO is quite likely a more efficient structure than splitting those jobs, yet it provides fewer checks and balances. We determined there were three options to deal with the failure of the CEO and the board of directors to address the wrongdoing that occurred on their watch. The first was to leave the governance structure intact and hope the other provisions of the deferred prosecution agreement (along with the presence of the federal monitor) would solve the problem. The second alternative was to demand the resignation of the chairman and CEO for failure to discover and address the wrongdoing. The third was a hybrid of the first two options, which was formulated during negotiations with corporate counsel. The reasoning behind this provision was two-fold: to have an active, experienced non-executive chairman act as an effective check on the CEO; and to insure that the CEO's office would not act as a bottleneck for information between the corporate officers and the board of directors. We believed this change would enhance the openness and effectiveness of the governance of Bristol-Myers. Eventually, management agreed with our assessment.

The Bristol-Myers deferred prosecution agreement requires the company to split the roles of board chair and chief executive [quoting $\llbracket 8$ ]:

Bristol-Myers shall establish the position of non-executive Chairman of the Bristol-Myers

Board of Directors (the "Non-Executive Chairman"), to advance and underscore the

Company's commitment to exemplary corporate citizenship, to best practices of effective corporate governance and the highest principles of integrity and professionalism, and to fostering a culture of openness, accountability and compliance throughout the Company. Bristol-Myers shall retain the position of Non-Executive Chairman at least throughout the term of this Agreement.

This approach, we feel, provides maximum board involvement in and accountability for BristolMyers' business decisions, including its public disclosures. The deferred prosecution agreement 
deliberately avoids any temptation to micro-manage the role of the non-executive chairman. Instead, it sets forth aspirational goals for the company and mandates information sharing with the non-executive chairman. [The article here quotes $\$ 10$.] It also gives the non-executive chairman a limited role in preparing for and monitoring quarterly conference calls with Wall Street analysts and investors. [The article here quotes \23.] The Board selected James D. Robinson III, a long-time Bristol-Myers Director, to fill this role.

In addition to splitting the roles of board chair and chief executive, the deferred prosecution agreement also requires Bristol-Myers to appoint an additional non-executive Director acceptable to the U.S. Attorney's Office. Our aim was to bring fresh blood and a new perspective to the board of directors; our preference for someone with a law enforcement background was made clear. Accordingly, BristolMyers selected, and the U.S. Attorney's Office approved, Louis J. Freeh, a former federal judge, federal prosecutor, and Director of the FBI, as the additional director.

Our conclusions regarding these governance issues were informed by meetings with both the CEO and the entire board of directors. The U.S. Attorney, along with the other prosecutors on the investigation, met a number of times with the CEO. One of the purposes of these meetings was to gain insight into the way management actually worked at Bristol-Myers. That knowledge helped us to intelligently and comprehensively negotiate a deferred prosecution agreement that dealt with the real problems at BristolMyers. The CEO gave us a real insider's view of how these events unfolded from his perspective.

We questioned the CEO regarding his relationship with his other senior officers, the board of directors, and his external auditors. We were attempting to find out every detail we could as to why the governance structures at Bristol-Myers had failed. By the very nature of the questions, these conversations were at times contentious. We discovered, however, that one of the root causes of the failures was the lack of timely and relevant information reaching all the decision makers at the top of the corporate chain of command. This led us to the conclusion that alternative information pipelines had to be opened in addition to the pipeline into the CEO's office. This further reinforced our conviction that the splitting of the chairman and CEO positions was a good idea.

Once we decided that the separation of the chairman and CEO's position was advisable, we felt that a meeting with the entire board of directors was necessary. We traveled to a regularly scheduled board meeting in Wilmington, Delaware and engaged in a ninety-minute open exchange with the Board. It was an opportunity to discuss previous conduct, and our ideas for future remediation, with the board. The Board shared with us their concerns about a deferred prosecution agreement and the potential effect on their business plans. Most importantly, we were able to gauge the commitment of the Board to real change in governance. The meeting also gave us the chance to assess each board member in light of our desire to potentially find a non-executive chairman who had a deep knowledge of Bristol-Myers and a real desire to be an agent of change of the corporate culture, which created these issues in the first place.

These corporate governance changes, along with the other governance measures Bristol-Myers adopted prior to the deferred prosecution agreement are no guarantee of perfectly smooth sailing during the term of the agreement. Regardless, this increased internal accountability should go a long way toward achieving the goal of good corporate citizenship. We believed, however, that more was needed from outsiders to insure compliance with the agreement and a change in corporate culture.

The maxim "trust but verify" applies in deferred prosecution agreements. From the prosecutor's point of view, it would be highly irresponsible to allow a corporation whose prosecution is being deferred to go unsupervised during the deferral period. Bristol-Myers, to its credit, recognized at the inception of the investigation, and long before we began to negotiate the terms of the deferred prosecution agreement, that outside help would benefit the company. The company retained as an independent advisor the Honorable Frederick B. Lacey, a former U.S. Attorney and federal judge in the District of New Jersey, and gave him a broad mandate to review the company's internal controls, financial reporting, disclosure, compliance, and budget processes. We requested, and Bristol-Myers agreed, to expand Judge Lacey's role to become the 
independent federal monitor at Bristol-Myers.

The independent monitor has wide authority to oversee Bristol-Myer's compliance with the deferred prosecution agreement and strengthen its ongoing remediation efforts. [The DPA at \12] charges the monitor to perform the following tasks, among others:

(a) Monitor Bristol-Myers' compliance with this Agreement, and have authority to require Bristol-Myers to take any steps he believes are necessary to comply with the terms of this Agreement; (b) Continue the review, reforms and other functions undertaken as the Independent Advisor; (c) Report to the Office, on at least a quarterly basis . . . as to Bristol-Myers' compliance with this Agreement and the implementation and effectiveness of the internal controls, financial reporting, disclosure processes and related compliance functions of the Company; (d) Monitor Bristol-Myers' compliance with applicable federal securities laws, and in his quarterly reports make recommendations necessary to ensure that the Company complies with applicable federal securities laws.

The monitor's power is also significantly bolstered by his authority to make recommendations that Bristol-Myers must adopt "unless Bristol-Myers objects to the recommendation and the Office agrees that adoption of the recommendation should not be required." A strong, independent monitor is in a far better position to ride herd over a mammoth corporation than any U.S. Attorney's Office or Probation Office. Independent monitors are visible, on-site reminders that compliance with the terms of a deferred prosecution agreement is mandatory, not optional. Monitors are able to observe and understand the business they oversee, along with its personnel and processes, in ways that federal prosecutors never could or should. If the company views their monitor as a force for positive change and not as an unwanted burden, all sides benefit.

The central role of Judge Lacey in ensuring successful adherence to the spirit and letter of the deferred prosecution agreement by no means ends the role of the U.S. Attorney's Office in this matter. The agreement makes it clear that all participants-Bristol-Myers, the independent monitor, and the U.S. Attorney's Office-should treat the agreement as an opportunity to work together toward the common aim of making Bristol-Myers a model corporate citizen. The agreement provides for regular communication among the parties, requiring Bristol-Myers' CEO, non-executive chairman, and general counsel to meet quarterly with the U.S. Attorney's Office and the monitor. ["13] The quarterly meetings are an opportunity to discuss the monitor's quarterly reports and any other issues and concerns that may arise, to keep the lines of communication open, and to remind all of the importance of compliance with the agreement and the serious consequences breach of the agreement would have for the company, its shareholders, and employees.

The regular quarterly meetings have already proven to be useful and interesting. Prior to each meeting, we are provided with a 400-500 page quarterly progress report by the independent monitor. The report provides updates on Bristol-Myers' business operations, new legal issues arising in any of its operating entities, compliance with the deferred prosecution agreement, and a forward-looking section on issues Bristol-Myers will confront in the next quarter. We also exchange draft agendas prior to meeting so that all topics of interest to both parties are addressed. The attendees at the meeting include the nonexecutive chairman, the chief executive officer, the general counsel, the U.S. Attorney, his counsel, and the Assistant U.S. Attorneys who prosecuted the matter. The independent monitor presides at the meeting. To further emphasize the post-deferred prosecution agreement sense of partnership between the parties, the site of the meeting is alternated between our offices and [those of] Bristol-Myers. ...

In addition, to impress upon Bristol-Myers' top managers and finance personnel the seriousness of the company's situation, the deferred prosecution agreement also provides [in ๆ22] for "a meeting . . . of its senior executives and any senior financial personnel, and any other Bristol-Myers employees who the Company desires to attend, such meeting to be attended by the United States Attorney and other 
representatives of the Office for the purpose of communicating the goals and expected effect of this Agreement." ...

The deferred prosecution agreement recognized that Bristol-Myers had taken steps to change its budget process, to assure that appropriate consideration is given to input and analysis from the bottom to top, and not exclusively from top to bottom, and to adequately document that process. The agreement requires that Bristol-Myers management keep informed about its budget process and the perils of top-down budgeting, but does leave budgeting to Bristol-Myers management. [The DPA at \24] provides for highlevel reporting on issues that will reflect whether the old culture of hitting the numbers at all costs still lingers. It provides as follows:

The CEO and CFO shall prepare and submit to the Non-Executive Chairman, Chief Compliance Officer and the Monitor described in paragraph 11 written reports on the following subjects: (a) all non-standard transactions with major U.S. wholesalers, such written report to be submitted within fifteen (15) days of such transaction; (b) an overview and analysis of Bristol-Myers' annual budget process for its major business units, including description of significant instances of any top-down changes to business unit submissions, such written report to be submitted together with the proposed budget submitted for approval to the Board of directors; (c) sales and earnings forecasts or projections at the corporate or major business unit level which indicate a quarterly target will not be met, together with a description of steps subsequently taken, if any, to achieve the budget target, such written report to be submitted quarterly and at least ten (10) business days prior to the Company's scheduled quarterly analyst call; (d) description of significant instances in which the preliminary quarterly closing of the books of any major business unit indicated that the business unit would not meet its budget target for any sales or earnings measure.

The agreement [ $₫ 18]$ also requires Bristol-Myers to develop and implement a "training and education program, which shall be reviewed and approved by the board of directors, designed to advance and underscore the Company's commitment to exemplary corporate citizenship, to best practices of effective corporate governance and the highest principles of integrity and professionalism, and to fostering a culture of openness, accountability and compliance throughout the Company." . . .

Many of the remedial measures in the deferred prosecution agreement-the top-level structural and governance changes, the reporting by senior management, and the training and education programs for key financial and legal personnel-are designed to spread knowledge and responsibility for doing the right thing throughout the Bristol-Myers organization.

[The following paragraph appeared as footnote 29 in the article, addressing |29 of the DPA.] Another step taken by Bristol-Myers to try to change the corporate culture was the endowment of a chair in business ethics at Seton Hall University School of Law. The professor occupying that endowed chair is required to conduct an annual ethics seminar for Bristol-Myers management and other interested industry members. The idea for endowing the chair originated with counsel for Bristol-Myers. The only requirement from our Office was that the chair was endowed at a New Jersey law school. Rutgers University School of Law already had a chair in business ethics endowed by Prudential. Bristol-Myers, after the signing of the deferred prosecution agreement, entered into discussions with the Dean of Seton Hall Law School and formally endowed the chair in December 2005. 